\title{
THE GRACIOUS AMBIGUITY OF GRACE AGUILAR (1816-47): ANGLO-JEWISH THEOLOGIAN, NOVELIST, POET, AND PIONEER OF INTERFAITH RELATIONS
}

\author{
Daniel R. Langton*
}

\begin{abstract}
Grace Aguilar was an early nineteenth-century Anglo-Jewish writer who concerned herself with the reform of Jewish religion and its relationship to Christianity in her theological works, novels, and poetry. She was interested in challenging the ways in which Jews and Christians represented each other in their teachings, tried to present both perspectives on the vexed question of Christian mission to the Jews, and sought to demonstrate that the theological barriers constructed between the two faiths were often less immoveable than tradition would have it. As a female Jewish theologian writing well before her time, she offered a remarkably innovative conception of female spirituality that allowed her to cross and re-cross the boundaries between the Jewish and Christian religious cultures she inhabited.
\end{abstract}

Any student of the history of Jewish-Christian relations is interested in Jewish views of Christianity. These views include 'relational theologies', that is, focused attempts by Jews to create a theological space for Christianity or to highlight the special relationship between Judaism and Christianity. As anyone familiar with the history of Jewish-Christian intercourse will know, such relational theologies have rarely been positive, and have tended to concentrate upon the construction and maintenance of the barriers that separate the two faith systems.' Over the centuries Jews have traditionally regarded the Christian as the idolatrous oppressor who denies the unity of God, prays to saints, worships icons, and abrogates the Torah. The Christian is perceived to have misinterpreted the scripture and to be profoundly mistaken in claiming that the messianic age has begun. At best, Christianity has been understood as an instrument of God to help prepare the pagan world for the coming of the Jewish messiah, or to test the faith of his Chosen People. Against this backdrop, a positive, or constructive, or appreciative Jewish view of Christianity stands out starkly. In particular, positive relational

\footnotetext{
* Professor of the History of Jewish-Christian Relations at the University of Manchester. Email: daniel. langton@manchester.ac.uk. An earlier draft of this paper was first presented at the conference of the British Association for Jewish Studies (BAJS) in Birmingham in 2005.

${ }^{1}$ Some well-known studies that emphasise the antagonistic nature of Jewish and Christian conceptions of the other include: James Parkes, The Conflict of the Church and the Synagogue: A Study in the Origins of Antisemitism (London: The Soncino Press, 1934), Jules Isaac, The Teaching of Contempt: Christian Roots of Anti-Semitism, 1st ed. (New York: Holt, 1964), Rosemary Radford Ruether, Faith and Fratricide: The Theological Roots of Anti-Semitism (New York: Seabury Press, 1974), Hans Joachim Schoeps, The Jewish-Christian Argument: A History of Theologies in Conflict [1st ed. (New York: Holt, 1963), Edward H. Flannery, The Anguish of the Jewes: Twenty-Three Centuries of Anti-Semitism (New York: Macmillan, 1965), Franklin H. Littell, The Crucifixion of the Jeres, 1st ed. (New York: Harper \& Row, 1975), Marc Saperstein, Moments of Crisis in Fewish-Christian Relations (London: SCM Press, 1989), Joel Carmichael, The Satanizing of the Jews: Origin and Development of Mystical Anti-Semitism, 1st U.S. ed. (New York: Fromm International Pub. Corp., 1992), Leon Sheleff, In the Shadow of the Cross: Fewish-Christian Relations through the Ages (London: Vallentine Mitchell, 2004).
} 
theologies, which have only begun to emerge in significant numbers in the modern period, are often regarded by Jewish commentators as inauthentic, or heretical, or unJewish. Examples might include theologians such as Claude Montefiore, ${ }^{2}$ or historians such as Joseph Klausner, ${ }^{3}$ or writers such as Scholem Asch ${ }^{4}$ and Franz Werfel. ${ }^{5}$ And this raises a host of questions about the nature of appreciative Jewish theologies of relation. What historical, social and personal factors account for such a theological endeavour? How do different ideological assumptions and different methodological approaches affect the reception of such an attempt? At the heart of the matter lies the issue of authenticity and a sense that the line has been crossed. What is it about the generation of an appreciative theology of relation which appears to undermine the theologian's Jewishness? Or to put it another way, does the brush with Christianity leave an enduring trace, and is it this which accounts for such suspicions?

This is the context for the following discussion of the theology of Grace Aguilar. Rather than offer a literary analysis or historical contextualization of her writings, which can be found elsewhere, ${ }^{6}$ the focus here will be on the theological meaning and implications of her positive appreciation of Christianity and Christians for her conception of Judaism. In her writings, which span a wide range of literary genres, Aguilar was struggling to define the precise nature of the relationship between Judaism and Christianity. While she offers a positive appreciation of Christianity on many levels, we must acknowledge from the start her

2 The biblical scholar and co-founder of Anglo-Liberal Judaism, Claude Montefiore, with respect to his Synoptic Gospels (1909) was criticised by Ahad Ha-Am who claimed he had detected "a subservience of the Jewish thinker to the Christian doctrine". Ahad Ha-Am, 'Judaism and the Gospels', reprinted in American Hebrew fournal, LXXXVII, no. 21 (23 September 1910) from The Jewish Review, I (3 September 1910), 203.

${ }^{3}$ Klausner, a prominent Zionist and disciple of Ahad Ha-Am, saw his historical study Fesus of Nazareth (1929) attacked as 'a trucking and kow-towing to the Christian religion, and an assertion of great affection for the foggy figure of its founder, a denial of the healthy sense of our saintly forefathers'. Aaron Kaminka in Ha-Toren (New York) May 1922, cited in H. Danby, The Jew and Christianity; Some Phases, Ancient and Modern, of the Jewish Attitude Towards Christianity (1927), 102-103.

${ }_{4}$ Amongst the many and varied criticisms Asch incurred for his Christian-themed novels The Nazarene (1939), The Apostle (1943), and Mary (1949) was a book-length polemic, published in 1953, in which he is described as having 'carried on in the course of years a missionary activity on a scope never before known among Jews' and in which his treatment of Paul was castigated as a betrayal of Judaism. Chaim Lieberman, The Christianity of Sholem Asch: An Appraisal from the Jewish Viewpoint, trans. from the Yiddish by A. Burstein (New York: Philosophical Library, 1953), 1, 139.

${ }^{5}$ In response to a barrage of inquiries as to his baptismal status, following the debut of his play Paul Among the Jerws: A Tragedy (1926), Werfel insisted in one newspaper interview: 'I have never moved away from Judaism, I am in feeling and thinking a conscious Jew.' Interview with Israelisches Wochenblatt (1926), cited in L.B. Steiman, Franz Werfel (1985), 222n3.

${ }^{6}$ Aguilar features prominently in a good number of works of literary scholarship, including: Michael Ragussis, Figures of Conversion: Fewish Question and the English National Identity (Durham: Duke University Press, 1995); Michael Galchinsky, The Origin of the Modern Fewish Woman Writer: Romance and Reform in Victorian England (Detroit: Wayne State University Press, 1996); Cynthia Scheinberg, Women's Poetry and Religion in Victorian England: Fewish Identity and Christian Culture, Cambridge Studies in Nineteenth-Century Literature and Culture 35 (Cambridge, UK; New York: Cambridge University Press, 2002); Cynthia Scheinberg, Women's Poetry and Religion in Victorian England: Jewirsh Identity and Christian Culture, Cambridge Studies in Nineteenth-Century Literature and Culture 35 (Cambridge, UK; New York: Cambridge University Press, 2002); Michael Galchinsky, Grace Aguilar: Selected Writings (Peterborough, Ont.; Orchard Park, NY: Broadview Press, 2003); Judith W. Page, Imperfect Sympathies: Fewes and Fudaism in British Romantic Literature and Culture (London: Palgrave, 2004); Judith W. Page, 'Anglo-Jewry and the Politics of Cultivation in Hazlitt, Aguilar and Disraeli' in Sheila A. Spector, The Jewes and British Romanticism: Politics, Religion, Culture (New York; Basingstoke: Palgrave Macmillan, 2005); Nadia Valman, The Jewess in Nineteenth-Century British Literary Culture, Cambridge Studies in Nineteenth-Century Literature and Culture (Cambridge: Cambridge University Press, 2007). 
ambiguity. It will be argued that this ambiguity can be explained in part by the complications attendant to drawing upon Christianity in her reforming programme for Judaism - and her keen awareness of the dangers she ran in the eyes of many of her co-religionists. It will be suggested that Aguilar's ambivalent presentation of Christianity and unfamiliar ways of expressing her Jewish identity are instructive in terms of understanding why some theologies of relation are so often regarded as somehow inauthentic or compromised. ${ }^{7}$

Aguilar's is not a systematic theology, and some of the interpretations offered here are necessarily tendentious. In particular, one might ask: How sound is a methodology that frequently attributes to Aguilar's fictional characters her own opinions? How much weight can be given to writings that were published posthumously and which she herself might never have wished to publish? In answer to such questions, the defence made here is that it is only when similar ideas can be found elsewhere in her written corpus that her fiction or posthumous writings will be treated as reliable expressions of her own theology. Likewise, the unsystematic nature of her work makes it particularly vulnerable to mistaken emphases and misunderstandings, and so an attempt will be made to focus upon themes and ideas that appear repeatedly in a wide variety of her writings. In the systematic survey that follows, then, Aguilar's views of Judaism and Christianity will be organised according to three themes crucial to her religious identity. That is, we will consider the way in which she (i) drew upon and privileged her individual or personal experiences, (ii) related this to her tradition and scriptures, and (iii) related both of these to her community and to the relationship between Jews and Christians.

\section{Biographical remarks}

Grace Aguilar (1816-1847) has been described as the most important female Jewish writer in the nineteenth-century, and, as already mentioned, it is literary critics who have taken the

\footnotetext{
${ }^{7}$ As we shall see, Aguilar herself was only too aware of the risks of presenting a positive appreciation of the traditional enemy, and a heightened consciousness of her vulnerability to the charge of Christianizing suffuses all her writings. It would not have helped that in Aguilar's own day Christian conversionist periodicals praised her books as being 'imbued with the spirit of Christianity.' Unsigned review of The Spirit of Fudaism in Fewish Herald 3 (July 1848), 29, cited in Valman, The Jewess in Nineteenth-Century British Literary Culture, 98. Later commentators have frequently used the language of compromise and bargaining, even if they did not doubt that she was a committed Jew. Galchinsky has argued that Aguilar 'bargained' with the dominant British Christian culture and was prepared to confine Jewish ritual and practice to the private sphere of the home, with the public lives of her characters less obviously Jewish. Galchinsky, The Origin of the Modern Jewish Woman Writer, 135-151. Page has mused as to whether 'all of the difficult balances and compromises' to be found in a writer like Aguilar, in contrast to one like Benjamin D'Israeli, are more likely for 'a more Jewish writer seeking to appeal to a wider audience in the Victorian period.' Page, 'Anglo-Jewish Identity and the Politics of Cultivation in Hazlitt, Aguilar and Disraeli', 19, and Page, Imperfect Sympathies, 161. Some have focused explicitly on the apparent influence of Christianity. Lask-Abrahams described the anti-traditional aspects of Aguilar's thought as 'a form of Jewish Protestantism'. Beth-Zion Lask-Abrahams, "Grace Aguilar: A Centenary Tribute" in Jewish Historical Society of England Transactions 16 (1952), 142. Valman sees Aguilar's conception of a bibliocentric Judaism as 'a Jewish imitation of an Evangelical [Christian] form of imitation of Judaism', and goes on to suggest that Aguilar not only adopted literary genres popularised by the Evangelical Christians but 'also echoed their theology', and dedicates a section aside to consider the extent to which one might describe her as a 'Jewish Evangelical?' While Valman certainly regards Lask-Abrahams' comment on Jewish Protestantism as 'apt', her chief object is 'to consider how Protestant rhetoric was able to provide her with a persuasive polemical strategy for the cause of the Jews'. Valman, The Fewess in Nineteenth-Century British Literary Culture, $10,92,94,95$.
} 
greatest interest in her. ${ }^{8}$ She belonged to a traditionally observant Sephardic family from Hackney, London, although, in her youth, she made Christian friends and attended Protestant services near her family's somewhat isolated rural home in Devonshire and later in provincial Brighton. ${ }^{9}$ There is no evidence that she ever seriously contemplated conversion and she herself records that she attended these services in some trepidation, fearful that people would think she had abandoned her faith. ${ }^{10}$ According to one report, Aguilar solved the problem for herself by "altering those parts of the prayer-book which she could not join to her belief." While she herself regarded her attendance at these Christian services as a way of clarifying her own Jewish sensibilities, there can be little doubt that this exposure to Christianity is also important in terms of familiarising her with how Judaism and Jews were represented within Christian culture. For most of her life she taught at a private boy's boarding school run by her mother where, amongst other things, she taught Hebrew. ${ }^{12}$ She was of fragile health, and died while convalescing in Germany, aged only 31.

Aguilar had been a precocious child, reading and writing voraciously from an early age. Of her 15 books, seven were published posthumously by her mother. ${ }^{13} \mathrm{~A}$ series of her letters to Isaac D'Israeli, from 1840 until 1844, now held at the Bodleian in Oxford, make clear with just what difficulty she won literary patrons and assistance for publishing her works. ${ }^{14}$ Despite this, after her death a number became what we would now call best-sellers, specifically her novels Home Influence (1847) and The Vale of Cedars (1850). ${ }^{15}$ The readership of her books was mixed. It is clear from dedications and prefaces that she intended Jewish and Christian mothers and daughters to benefit from her novels and from her anthologies, such

\footnotetext{
${ }^{8}$ As several have noted, Aguilar is a constant fixture in modern anthologies of Jewish women writers. Scheinberg, Women's Poetry and Religion in Victorian England, 146. Galchinsky, The Origin of the Modern Fewish Woman Writer, 135.

${ }^{9}$ In a work which arguably should be read semi-autobiographically, Aguilar writes "Our very position as aliens in a land whose religion is not ours. . . in a small country town almost entirely surrounded by Christians. . . must increase the mental difficulties you are now enduring. . . Like my own early youth, circumstances have thrown you almost entirely among Protestants; and from your peculiar disposition, longing unconsciously for the high and pure, you have always made those your intimate friends who are serious thinkers". Grace Aguilar, The Jewish Faith: Its Spiritual Consolation, Moral Guidance and Immortal Hope (Philadelphia: L. Johnson, 1846), 34.

${ }^{10}$ There are several examples of this among the poetry contained in her handwritten manuscripts. 'Aguilar Papers' (1831-1853), MS ADD 378 University College London.

${ }_{11}$ Lask-Abrahams quotes a letter from an unnamed Christian sent to Aguilar's mother, "Her love for many Christian friends, and her desire to search after truth in every garb, induced her to attend Trinity Chapel [Brighton] frequently on a Wednesday when there was a lecture on the Old Testament, and she joined in the prayers and there with the congregation, altering those parts of the prayer book where [sic] she could not join to her own belief." Lask-Abrahams, "Grace Aguilar: A Centenary Tribute", 139.

${ }^{12}$ An advertisement in the Voice of Facob (March 1842) indicates the range of subjects taught: "Mrs and Miss Aguilar's Preparatory Establishment for Young Gentlemen, from four to ten years of age, No. 5 Triangle, Hackney, with liberal board, and instruction in Religion, the English and Hebrew languages, Writing, Arithmetic, Geography and History." Cited in Ibid.: 141.

${ }_{13}$ Before her death she published The Magic Wreath (1839), Israel Defended (1838), The Spirit of Fudaism (1842), The Perez Family (1843), Records of Israel (1844), Women of Israel (1845), The Jewish Faith (1846), 'History of the Jews in England' (1847). After her death, her mother edited and published The Vale of Cedars (1850), Woman's Friendship (1850), A Mother's Recompense (1851), Days of Bruce (1852), Home Scenes and Heart Studies (1852), Essays and Miscellanies (1853), Sabbath Thoughts and Sacred Communings (1853). One must obviously be extremely cautious about any conclusions reached from readings of posthumous works which the author herself had not had published.

${ }^{14}$ Correspondence between Grace Aguilar and Isaac D'Israeli (1840-44) Dep.Hughenden 243/1 fols.3-12, Modern Papers, Bodleian Library, Oxford. As a well-regarded man of letters, D'Israeli (1766-1848) wrote the antirabbinic The Genius of Fudaism, published in 1833.

15 These ran into very many editions, and adverts for her works can be found in the end-pages of Dickens's Bleak House, as Galchinsky points out. Galchinsky, The Origin of the Modern Fewish Woman Writer: Romance and Reform in Victorian England, 135, 139.
} 
as Women of Israel (1845). The same was true for her more formal theological works, such as The Spirit of Fudaism (1842) and The Ferwish Faith (1846) - although in writing these studies she was also highly conscious of a male audience, again both Christian and Jewish. ${ }^{16}$ Aguilar's mid-nineteenth-century historical context was that of Victorian religiosity and the emergence of Anglo-Reform Judaism and the establishment of the West London Reform Synagogue in 1840, which she appears to have regarded with mixed feelings. The influence of her Sephardi background is also important. Crypto-Jewish families in early-modern Portugal or Spain, that is, Jewish families pretending to be Christian on pain of death or expulsion, could only have risked expressing their Judaism within the secret realm of the home, the territory of the mother. Aguilar believed that her own family history offered a precedent for a woman storyteller who took responsibility for the generational transmission of Jewish identity. ${ }^{17}$

What were Aguilar's aims, broadly speaking? From even a cursory glance at her various works, it is clear that she had set out from the beginning to persuade Christians to respect Judaism, and to encourage and develop among Jews, especially Jewish women, a pietistic form of spirituality. She was concerned to break down the fence that separated the true exponents of the two faiths, or, at least, she was concerned that the fence should not be allowed to impede the development of good relations between neighbours. And from a collection of copied newspaper clippings and letters now held at the UCL archives, there is no doubt that she was indeed an inspiration to many in these regards. ${ }^{18}$ That she was influential in her own day is demonstrated by the national weekly fewish Chronicle's front page treatment of her death.

\section{(i) Aguilar's Personal Understanding of the Essence of Religion: Spiritual piety}

Although Aguilar wrote works of formal theology throughout her life, The Spirit of Judaism (published in 1842, after having lost the original 1837 draft) was the only example printed before her death. ${ }^{19}$ This systematic treatment used the text of the Shema as a means by which to teach the key characteristics of Judaism; each chapter was an exegesis of a section from the Shema. ${ }^{20}$ Its pious tone ${ }^{21}$ meant that it acted as a kind of devotional commentary at the

\footnotetext{
${ }^{16}$ Another important collection of theological meditations was Grace Aguilar, Sabbath Thoughts and Sacred Communings (London: Groombridge and Sons, 1853).

17 Galchinsky regards as crucial this aspect of Aguilar's psychological make-up. Galchinsky, The Origin of the Modern Fewish Woman Writer: Romance and Reform in Victorian England, $137 \mathrm{ff}$.

18 'Aguilar Papers' (1831-1853), MS ADD 378 University College London.

19 Grace Aguilar, The Spirit of Fudaism, ed. Isaac Leeser (Philadelphia: Jewish Publication Society of America, 1842). This was originally written in 1837. Also posthumous was Grace Aguilar and Sarah Aguilar, Essays and Miscellanies (Philadelphia: A. Hart, 1853), which included commentaries on the prophets Daniel and Isaiah, liturgical prayers, and a series of 'Sabbath Thoughts' which refute certain Christian claims about Judaism and Jews.

${ }^{20}$ Chapter headings include: 1: The Avowal of Unity considered as it regards the Jewish nation; 2: Definition of the word Heart - Love of God considered as it regards the affections; 3: Definition of the word Soul - Love of God considered as it regards the Intellectual and Vital Principle of Man; 4: Definition of the word Might - Love of God as considered as it regards our domestic and social duties; 5: Brief review of the commandments and the Social Duties therein described; 6: Hints on the religious instruction of the Hebrew Youth; 7: The spirit of religion regarded as pervading and guiding our conversation, profane reading, admiration of works of nature; 8: The spirit and forms of Judaism considered separately and together.

${ }^{21}$ Lask-Abrahams sees it as typical of "the Sunday-School character of a great deal of Grace Aguilar's writings." Lask-Abrahams, "Grace Aguilar: A Centenary Tribute", 142.
} 
same time as exploring a variety of theological themes and controversies. That this was an unusual undertaking for an English Jewess is suggested by its publication through the offices of an American rabbi, Isaac Leeser. ${ }^{22}$ Within The Spirit of Fudaism, Aguilar presented religion as powerfully connected with emotion. "Religion" she said, "is strongest, loveliest, in those hearts ever susceptible to emotion, whether pleasure or pain; the love of their God glows warmest in such bosoms. ${ }^{\prime 23}$ Feeling was certainly as important as traditional learning, which could not generate the gentle and loveable qualities of the person of true faith. ${ }^{24}$ Those who disagreed with her, she said, devalued the prayers of the unlearned and were presumptuous and haughty "like the Pharisees of old," ${ }^{25}$ a comparison that riled her editor. ${ }^{26}$ The long-suffering Jew, she argued, had greater need of this kind of faith than the Christian, and could easily point to his Bible to demonstrate Israel's original discovery of the God of love. ${ }^{27}$ External forms and religious ceremonies were of far less importance than was the life of the spirit, ${ }^{28}$ and she drew on her own family history of Iberian crypto-Jews to make this point.

The determination, in secret to adhere unchangeably to the Law of Moses, incited many to live a holier life, and ponder frequently on Him, in whose service their very lives were risked. When occupying posts of high trust and favour in the Spanish court, their lineage unknown, their race unsuspected, though they could scarcely keep the forms, the SPIRIT glowed more warmly within. $^{29}$

This sounds like the familiar classic Anglo-Reform Jewish argument which set spirit against form. ${ }^{30}$ But in fact Aguilar went on to argue that the ideal was obedience to God's ordinances, including external forms, through the power of the spirit. She wrote,

${ }^{22}$ Isaac Leeser (1806-1868) was a Philadelphia-based lay minister of religion, prolific author, translator, and founder of the Jewish Publication Society. Aguilar's argument is constantly undermined by Leeser's patronizing corrections and often openly critical claims of exaggeration or inaccuracy (e.g. regarding her apparent exaggeration of the number of converts to Christianity; and of the extent of Jewish neglect of Bible). His rare agreements tend to be in the form of provision of biblical or rabbinic references or of a fuller/better explanation of the point.

${ }^{23}$ Aguilar, The Spirit of Judaism, 46-47.

24 "Precept is too often doubted; we look on professors of religion with a jealous eye; and if they fail, the effect of their most eloquent appeal is lost entirely. But very different is the effect of discovering religion to be the secret source in each and all of those gentle and loveable qualities which in the first instance attracted us. At first we admire and revere at a distance, then as we draw near and love, comes the question, why cannot we too 'go and do likewise?'. . . When well-selected words flow glibly from eager lips, and an ardent eloquence appears to bear all its hearers along with it: the spirit is ready to condemn others, as far as its inferiors in religious fervour, simply because they cannot speak so well; and yet, while the lips may speak so piously and well, the heart may remain stubborn and unmoved." Ibid., 94, 184.

25 " $[\mathrm{A}]$ nd yet does the presumptuous and haughty Hebrew, imitating the Pharisee of old, dare to say, their prayers are less acceptable than his [the meek and lowly]?" Ibid., 19.

${ }_{26}$ The editor, Leeser, commented that "my friend has adopted without sufficient care the opinions [regarding the Pharisees] which our opponents entertain of these people." Ibid.

27 "Is he [the Hebrew] accused of having no faith, let him prove he has more need of faith, and feels it yet more deeply than the Nazarene. . . Is he told his is a stern, cold, spiritless religion, that can only look to a rigid and exacting Judge, in whom mercy is lost in justice: let him bring forward his Bible to prove that a God of love was revealed to the Israelites, many centuries before the birth of him the Christians call their messiah." Ibid., 90.

28 "[Religious ceremonies] are given to aid and strengthen the spirit of piety, resting within this spirit, yet NOT to take its place. . . The form. . . springs from, and yet assists the spirit resting within. Thus should every Hebrew rite be considered, and reason, not superstition, be traced as its foundation.” Ibid., 216, 227.

${ }^{29}$ Ibid., 85.

${ }^{30}$ See for example, the classic study of the worldwide movement, Michael Meyer, Response to Modernity (Oxford: Oxford University Press, 1988). See also the slightly more recent study of Anglo-Reform Judaism, Anne Kershen and Jonathan Romain, Tradition and Change (London: Vallentine Mitchell, 1995). 
Yet while we feel and acknowledge the insufficiency of form alone: the sons of Israel must beware of the contrary extreme. . . If they adhere not to the rites of their forefathers, they cannot take unto themselves the gracious promises made to the children of Israel; for their religion degenerates into that, which is termed, natural theology; in a word, they are Deists not Hebrews, and they deprive themselves alike of faith, hope, and comfort. . . There are many, very many laws, which, if the Hebrew would still manifest himself as the first-born of the Lord, he can still implicitly obey ... the religion of no Hebrew is perfect, unless the form be hallowed by the spirit, the SPIRIT quickened by the FORM. ${ }^{31}$

Again drawing upon her Sephardi heritage, Aguilar argued that it fell to Jewish mothers to inculcate the true spirit of Judaism within their children, for they did not enjoy the same cultural encouragements for religion that Christian children did at home and in the wider society.

The Hebrew child has not these advantages [of the Christian child]. Debarred from the public exercise of devotion on his Sabbath day; never hearing public prayers in a language he can understand; - having no public minister on whom he can call for that instruction he may not have received at home; - never hearing the law expounded, or the Bible in any way explained: to his mother alone the Hebrew child must look, on his mother alone depend for the spirit of religion

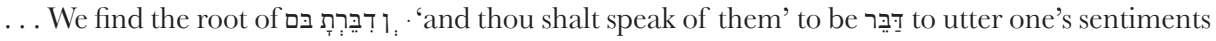
aloud, to speak or to converse together. . Yet when do we speak of these things? When, even amidst a domestic circle, does conversation turn upon these topics which would enable us to obey this command? ${ }^{32}$

Aguilar went on to suggest that powerful tools in this sacred duty of education included the study of God's providential work within history, the reading of edifying literature ${ }^{33}$ and the cultivation of wonder at his creation of the natural world. ${ }^{34}$ Once the Jewish child had been sensitized spiritually, the result would be a proud Hebrew, fully able to relate the traditions of his fathers to his loving Heavenly Father. As she put it,

[Properly educated by his mother] It will be [the Hebrew's] pride to prove to the nations the spirit of his faith. . . He will not throw off the bondage of our [external] forms, he will not condemn their dictates; for he will trace their minutest regulations to the same merciful Father, whose love supports, whose arm sustains him. ${ }^{35}$

31 Ibid., 235-236, 254.

32 Ibid., 147-148, 150, 181, 182.

33 "There is scarcely any profane history which, if read attentively, will not afford matter for instruction, thought, and subsequent conversation on the wonderful providence of the Lord. . . Did the spirit of piety pervade, as was intended, the intellect, those very works read for profane instruction would assist to promote obedience to the command we are regarding. Nor is it only history that may do this. There are tales, simple, domestic, highly moral tales, which, though as a whole fictitious, are in the main point but narrations of what, could, but we lift up the veil of the world, is continually passing around us." Ibid., 192-193.

34 "There are others again who, continually eulogizing Nature, yet never seem to cast a thought, or speak a word of God. . . The mind thus capable of admiring Nature for herself, is peculiarly fitted to adore and love her God. Nature is not herself a deity. She is the frame, not the FRAMER, the created, not the CREATOR." Ibid., 197-198. This interest in nature was non-trivial. In her eulogy for Aguilar, Anna Maria Hall wrote that Aguilar "had made acquaintance with the beauties of English nature during a long residence in Devonshire; loved the country with her whole heart, and enriched her mind by the leisure it afforded; she had collected and arranged conchological and mineralogical specimens to a considerable extent; loved flowers as only sensitive women can love them; and with all this was deeply read in theology and history.' Ana Maria Hall, 'Pilgrimage to the Grave of Grace Aguilar' in Galchinsky, Grace Aguilar: Selected Writings, 359.

35 Ibid., 161. 
Such a spiritual education would result in a Jewish faith that would properly testify to the surrounding Christian nations and support the eternal truths of Judaism. ${ }^{36}$ Aguilar felt obliged to make this point because she knew that her emphasis upon the need to inspire spirituality within the Jewish community would sound suspiciously alien to many within that community ${ }^{37}$ And, indeed, this provoked criticism that The Spirit of Judaism was not so much a work of Jewish theology, but rather one that drew too heavily upon her own idiosyncratic experiences in the Christian community for its conceptualisation of spirituality. ${ }^{38}$

To gain a clearer picture of this ideal Jewish spirituality, it is useful to consider Aguilar's epic mix of scriptural commentary and literary imagination entitled Women of Israel (1845). In this multi-volume work of 576 pages, Aguilar used the lives of biblical and historical Jewish women as a source of spiritual strength and inspiration for modern Jewish women. One biographical sketch, that of Deborah, will suffice. Aguilar viewed Deborah as an excellent role model for Jewish women, combining as she did prophet, judge, military instructor, poet and sacred singer; her very existence and accomplishments demonstrated that Jewish women were not degraded within Judaism, as some claimed. ${ }^{39}$ But while recognition of poetic abilities was granted, Aguilar felt that this was not where Deborah's true greatness lay. Nor was it in her military role in Barak's victory over Sisera. ${ }^{40}$ Crucially, Aguilar played down Deborah's outward power and public triumphs and emphasised instead her private role, focusing in particular upon her influence as a local judge after she returned home. ${ }^{41}$ The important thing to notice here, Aguilar claimed, was that Deborah's quiet, low-

36 "Every Hebrew should look upon his faith as a temple extending over every land, to prove the immutability, the eternity of God, the unity of His purposes, the truth of the past, the present, and the future; and regard himself as one of the pillars which support it from falling to the ground, and adds, however insignificant in itself, to the strength, the durability, and the beauty of the whole." Ibid., 245.

37 "Many Hebrews may perhaps object to the lengthened consideration of the second verse of the SHEMANG, which the three preceding chapters contain; that it is following the false lights of the Nazarene, and spiritualizing and mystifying a simple truth; that the command to love the Lord with all our heart, and soul, and might, simply means to pray to Him and praise Him, and obey His laws as far as lies in our power." Ibid., 109.

${ }^{38}$ For example, Lask-Abrahams comments, "One also has the feeling that her frequent decrying of traditional usages represents a form of Jewish Protestantism drawn from her early close association with non-Jewish acquaintances. . . [This] led her sometimes to oppose the Bible to the traditions of the Rabbis and minimize the role of the Rabbis in the development and spirituality of Judaism." Lask-Abrahams, "Grace Aguilar: A Centenary Tribute," 142.

39 "Had there been the very least foundation for the supposition of the degrading and heathenizing of the Hebrew female, we should not find the offices of prophet, judge, military instructor, poet and sacred singer, all combined and all perfected in the person of a woman." Grace Aguilar, The Women of Israel, or, Characters and Sketches from the Holy Scriptures and Fewish History, Illustrative of the Past History, Present Duties, and Future Destiny of the Hebrew Females, as Based on the Word of God (London: Routledge, 1845), 12.

40 "[After her and Barak's victory over Sisera] We next find Deborah exercising that glorious talent of extempore poetry only found among the Hebrews; and by her, a woman and wife in Israel, possessed to an almost equal degree with the Psalmist and prophets, who followed at a later period. . We find her taking no glory whatever to herself, but calling upon the princes, and governors, and people of Israel to join with her in 'blessing the Lord for the avenging of Israel.'. . The simplicity and lowliness of the prophetess' natural position is beautifully illustrated by the term she applies to herself - neither princess, nor governor, nor judge, nor prophetess, though both the last offices she fulfilled - 'until that I, Deborah, arose, until I arose a MOTHER in Israel.' She asked no greater honour or privilege for herself individually, than the being recognised as the mother of the people whom the Lord alone had endowed her with power to judge." Ibid., 214-215.

41 "[Deborah's] judgments, her works, are covered with a veil of silence, but we learn their effects by the simple phrase, that 'the land had rest for forty years' - the land, the whole land, not merely that which was under her direct superintendence. Virtue, holiness, and wisdom, though the gifts of but one lowly individual, are not confined to one place when used, as were Deborah's, to the glory of God, and the good of her people. Silently and perhaps unperceived, they spread over space and time; and oh, how glorious must be the destiny of that woman, who, 
profile, unassuming work as a local judge, profoundly influencing the local community, so that "the land had rest for forty years" - a far more powerful demonstration of what a woman can achieve than were military exploits. ${ }^{42}$ This, she went on, offered a model for the present and future duties of contemporary women of Israel, even if the situation in the real world meant that they "can no longer occupy a position of such trust and wisdom in Israel". Women should embrace their role as influencers - without feeling the need to do so publicly. Married women can influence their husbands and their households and will thereby "influence society at large, secretly and unsuspectedly indeed, but more powerfully than [they] can in the least degree suppose." ${ }^{43}$ With many such examples in Women of Israel Aguilar made it clear that her ideal of womanly spirituality was a reassuringly traditional one, nonthreatening in its refusal to compete with men in the public sphere. ${ }^{44}$

Several years later, in a work of literary fiction called The Fewish Faith (1846), Aguilar returned to the subject of form over spirit. This was ostensibly a series of letters of religious advice from a Sephardi Jewess called Inez Villena to a young girl called Annie, who was contemplating conversion, having had only a nominal Jewish upbringing. Interestingly, Aguilar here reversed her earlier claim that the crypto-Jewish experience had encouraged a spiritual understanding of their faith. Instead, she now argued that that kind of AngloJudaism which privileged external form over spirituality had had its origins in the Sephardi experience of Inquisition and crypto-Judaism. Their lives had been habituated to caution and hurried, superficial observance, and their imposed tradition of "soulless obedience. . . [in which they] adhered so very strictly to the form, to the utter exclusion of the spirit of their religion", had continued upon their arrival in England. This state of affairs was, while understandable, a matter of regret. ${ }^{45}$ Attitudes were changing, of course, sometimes too

without one moment quitting her natural sphere, can yet by precept, example, and labour, produce such blessed efforts as to give the land peace, and to bring a whole people unto God! "Ibid., 216. "[T] he greatness of Deborah consisted not at all in outward state, in semblance of high rank, or in any particular respect or homage outwardly paid her; but simply in her vast superiority of mental and spiritual acquirements which were acknowledged by her countrymen, and consequently revered." Aguilar, The Women of Israel, 212.

42 "Yet the history of Deborah in no way infers that she was neglectful of her conjugal and domestic duties. There is an unpretending simplicity about her very greatness. . . To a really great mind, domestic and public duties are so perfectly compatible, that the first need never be sacrificed for the last." Aguilar, The Women of Israel, 217-218.

43 "Every married women is judge and guardian of her own household. She may have to encounter the prejudices of a husband, not yet thinking with her on all points; but if she have really a great mind, she will know how to influence, without in any way interfering. She will know how to serve the Lord in her household, without neglecting her duty and affection towards her husband; and by domestic conduct [she will be able to] influence society at large, secretly and unsuspectedly indeed, but more powerfully than she herself can in the least degree suppose." Ibid., 217.

${ }^{44}$ Such views reflected wider cultural norms, of course, as demonstrated by the popularity of contemporary authors such as Sarah Stickney Ellis who wrote The Women of England, Their Social Duties and Domestic Habits (London: Fisher, 1839), a work with which Aguilar was very familiar.

45 "In Portugal, as you know, to be even suspected as a Jew exposed our ancestors to all the horrors of the Inquisition, sequestration, torture, and often, death. The religion of our fathers, therefore, was instilled with such impenetrable secrecy, and so burdened with caution and the constant dread of discovery, that, to do more than attend to its mere elements, and keep the mind faithful to the doctrine of the Divine Unity and the perpetuity of the Jewish Faith, in contradistinction to the bewildering dogmas of saints, martyrs, infallibility of the Roman Church, masses, etc, was impossible. To become spiritual was equally so, for the Bible was a forbidden book to the Catholics, and therefore equally so to the secret Jews. Those, therefore, who from some immanent pressure of danger fled to other countries, were unable to throw off the caution of centuries. They could not realise that the yoke was so far removed from the necks, as to permit the public practice, and open confession of their faith. To speak of, or impart it, by means of reference to, and discussion upon the Bible, had so long been an utter impossibility, that it was scarcely unnatural, they should suppose it impossible still, when in reality no impossibility existed. This is the reason why so 
violently for Villena/Aguilar's own liking, but "a mighty movement", by which she meant Reform Judaism, had thankfully begun. ${ }^{46}$ The artifice of placing her own words in the mouth of an eminently sympathetic woman gave Aguilar greater intellectual freedom than she had had in The Spirit of Judaism. Here, in this work which did not purport to be a formal work of theology, she could talk at length about non-theological aspects of religion, including attitudes and feelings and, in so doing, draw heavily upon her own personal experience without fearing the attentions of religious authorities. (The Spirit of Fudaism had received some poor reviews). It was undoubtedly written with Jewish and Christian audiences in mind, concerned as it was to present Judaism in a positive light and to challenge common Christian misconceptions which, she felt, also influenced the Jews' own self-understanding. In this work, support for Reform Judaism seems less muted, as if Aguilar had begun to believe that it held the hope for Jewish spirituality.

Spirituality is a complex thing, of course, notoriously difficult to capture in dry works of theology. In addition to the fictional series of letters and the biographical studies of biblical women, Aguilar also experimented with historical romance. Although only published in 1850, Aguilar's The Vale of Cedars had been composed in the early 1830s and is a gothic tale of torture, persecution and unrequited love set in fifteenth-century Spain. ${ }^{47}$ It tells the adventures of a young crypto-Jewess, an intimate of Queen Isabella called Marie, her innocent Christian former beau who is blamed for the murder of her noble husband (also a crypto-Jew), and the consequences Marie must face when the truth of her Jewishness is revealed. Others have found in its pages a clear appeal for Jewish emancipation. ${ }^{48}$ Here, we are more interested in the way Aguilar uses this particular novel to explore unfamiliar forms of spirituality. To a Christian readership, the Jewess Marie is presented as a paragon of steadfast loyalty to her father and the religion of her fathers, a potential martyr with the sweetness of an angel, easily contrasted with the unspiritual, murderous dungeon-keepers of the Catholic Inquisition. For the Jewish audience, however, one is struck by the remarkable presentation of Catholic queen Isabella as a deeply spiritual and wise Christian, whose profound yet unseen influence upon her husband, Ferdinand, made her the epitome of womanly religious virtue. ${ }^{49}$ With somewhat broad brush-strokes, history is re-written to reveal that the Isabella has been tragically misunderstood, and that only under considerable duress from Torquemada was she reluctantly persuaded to institute the Inquisition and expel

\footnotetext{
many of our ancient Spanish and Portuguese families, when they came to England, adhered so very strictly to the form, to the utter exclusion of the spirit of their religion; and never spoke of nor attempted to teach it, except by desiring a soulless obedience, which had no power, when the young mind began to enquire for itself." Aguilar, The Fewish Faith: Its Spiritual Consolation, Moral Guidance and Immortal Hope, 35-36.

46 "If we compare the thoughts and sentiments on the religion of the Hebrews in almost all countries of the present day with those of fifty years back, we shall find that there has been, indeed, a mighty movement; though, as merely looking on the present, we may feel the movement is so small as to be almost invisible, and we sometimes are led to despond more than hope. We may watch too, with dread, the too violent reforms, the too indiscriminate clipping away of the old established, and so somewhat treasured forms; but better, far better, this agitation, than the stagnant waters of apathy and indifference, in which fifty years ago all Judaism was plunged." Ibid., 443-444.

${ }^{47}$ Galchinsky estimates its date of composition sometime between 1831 and 1835. Galchinsky, The Origin of the Modern Fewish Woman Writer: Romance and Reform in Victorian England, 139.

${ }^{48}$ Ibid., $137 \mathrm{ff}$.

49 "Isabella's real influence on the far less lofty and more crafty Ferdinand was so silent, so unobtrusive, that its extent was never known, either to himself or to his people, till after her death. .." Grace Aguilar, The Vale of Cedars, or, the Martyr (London: Groombridge and Sons, 1850), 218.
} 
the Jews. ${ }^{50}$ The queen is central to the story-line and her actions and prayers fill the climactic pages of the novel, as she struggles to see beyond Marie's heretical Jewish shell, and love her - and free her - despite her refusal to convert to Christianity. ${ }^{51}$ There are two observations that can be made about Aguilar's Isabella. Firstly, the painful irony that Isabella has such perverse difficulty in recognising the closely-related spirituality of the Jewess is a dramatically effective and poignant warning to the reader concerning contemporary Christian attitudes towards Jewish spirituality. Secondly, it is revealing that in the story Marie's primary concern in disclosing her Jewish identity is not that she will have to face the Inquisition, but that she will lose the love of her adored Christian patroness. ${ }^{52}$ This fear of Christian disapproval is a theme found in a number of Aguilar's writings.

In this brief survey of different works by which means we have explored Aguilar's personal understanding of Jewish spirituality, and in particular her call to a specifically womanly conception of spirituality, we might note an ambiguous attitude towards Reform Judaism, both cautious and hopeful. The same is true of her attitude towards Christianity. Aguilar is concerned to refute the claim that the importance she places upon spirituality reflects a Christian emphasis, and she is keen to make it clear that this focus is one way of preventing conversion. On the other hand, she values her interactions with Christians, adopts the Christian negative view of Pharisees, admires Christian family and social encouragement to religion to the extent of creating a caricature, and is concerned not only to convince Christians of the reality of Jewish spirituality but even hints at a fear of receiving their disapproval.

\section{(ii) Relating to Tradition and Scriptural Resources}

Integral to Aguilar's conception of true faith in her theological treatise The Spirit of Fudaism was the need to base it upon an authoritative foundation. This foundation was to be the divinely inspired Bible as transcribed by Moses,${ }^{53}$ which would provide all the defences a Jew needed against the temptations and threats of a Christian world. Her rationale makes this clear.

\footnotetext{
50 "Isabella had within herself all the qualifications of a martyr. Once impressed that it was a religious duty, she would do violence to her most cherished wishes. . . This spirit would. . . have led her a willing martyr to the stake; as it was this same spirit led to the establishment of the Inquisition, and the expulsion of the Jews - deeds so awful in their consequences, that the actual motive of the woman-heart which prompted them is utterly forgotten, and herself condemned." Ibid., 194. Torquemada, "the wily churchman" found it difficult to convince Isabella, and was only able to achieve it by emotional blackmail. Aguilar, The Vale of Cedars, or, the Martyr, 242-243, 292.

${ }^{51}$ Isabella's fear for Marie's soul obliges her to attempt her conversion, but the failure of the disputation (which features a learned cleric's doctrinal arguments), which certainly disappointed Isabella, did not stop her protecting Marie from "the necessity of severity" for which Torquemada called.

${ }^{52}$ Marie, alluding to the immanent revelation of her secret Jewish faith, cries "Oh, madam, thou wilt hear a strange tale tomorrow - one so fraught with mystery and marvel, that thou will refuse to believe it. . . And then, if thou hast ever loved me. . . whatever thou mayst hear, do not condemn me. . . do not cast me from thee." Aguilar, The Vale of Cedars, or, the Martyr, 135.

53 "It signifies little whether Moses received them [the Laws] literally from the mouth of the Lord, or felt within his soul the infused eloquence and wisdom, which impelled him to proclaim them to his countrymen. Every page of the Bible breathes the voice of God." Aguilar, The Spirit of Fudaism, 32. Aguilar assumes throughout the divine revelation to Moses (chapter 2 explicitly affirms this).
} 
It is alleged that it is dangerous to associate intimately with those of other creeds, that it is as dangerous to our faith as the open warfare of old. They are mistaken who thus think; were the Jewish religion studied as it ought to be by its professors of every age and sex; were the BIBLE, not tradition, its foundation and defence; were its spirit felt, pervading the inmost heart, giving strength and hope, faith and comfort: we should stand forth firm as the ocean rock, which neither tempest nor the slow, still constant dripping of the waters can bend or shake. ... [To] enable us to mingle amongst those of another creed, without fearing to imbibe it. . . the Bible must be our constant study. . . Faith indeed is the golden key to unlock its stores, for without faith its pages are in truth 'sealed'. . Those who deny its divine truths are neither Jewish nor Christian; for the acknowledgement of its divinity is equally binding to the one as to the other. ${ }^{54}$

Aguilar called for educational programmes that would familiarize Jewish youth with the texts themselves, enabling them to defend their beliefs. ${ }^{55}$ The Word of God was the only means by which the poor and uneducated could come to understand His will for them and abandon their "superstitions of tradition and prejudice which have shackled them for so long" ${ }^{56}$ Like the Reform minister David Woolf Marks, ${ }^{57}$ Aguilar felt that any "inventions of man" such as rabbinic tradition that "choke up the law of Love which came direct from Heaven. . . and confine the soaring spirit", should be set aside, for the Word of God alone was the source of all Jewish ethics. ${ }^{58}$ She was quick to condemn those who valued the rabbinic tradition over the Bible itself, arguing that this was a common cause of conversion, and she called for a Jewish translation of the Bible into English, which did not exist at that time. ${ }^{59}$ There is a debate around the origins for the bibliocentric, that is, bible-based, characteristics of many reform-minded British Jews in the mid-nineteenth-century, but it is certainly reasonable to read it as evidence for the influence of Evangelical Christian critique

\footnotetext{
${ }^{54}$ Ibid., 20, 22, 50-51.

55 Ibid., 175-177.

56 "The poor, even as children, need instruction in their religion; it will not come untaught, nor can its mild consoling lustre beam from the trammels of tradition, which must increase in incomprehensible obscurity with each new generation. [but rather via] the word in which infinity was revealed... We do not think enough on the good we may do our needy brethren by leading them to read and understand the word of God, by. . . inciting them to rise superior to the superstitions of tradition and prejudice which have shackled them so long, and to look to the Bibles alone for. . . their instruction how to live and for their hopes of immortality." Ibid., 100, 103-104.

57 One of the founding fathers of Anglo-Jewish Reform, and minister at the West London Synagogue of British Jews for fifty-three years, the approach adopted by Marks (1811-1909) was characterised by its bibliocentricism and anti-rabbinism.

58 She went on: "All who seek to know the Jewish ethics, will find them in the word of God; for it is to the ordinances of Scripture alone we refer. There may be some observances which superstition and bigotry have introduced, some of which tarnish and choke up the law of love which came direct from Heaven; but to them we allude not. The Bible and reason are the only guides to which the child of Israel can look in security. The laws for which we can find no foundation in the one, and which will not stand the test of the other need no farther proof, they are not the dictates of the law, they are wanderings from the true and true and only law, the inventions of man, and not the words of God... It is therefore evident that those observances which not only confine the soaring spirit, but frequently occasion ordinances of far more weight to be neglected, and for which no reason can be assigned save the ideas of our ancient fathers, cannot be compared in weight and consequence to the piety of the heart, which but too often they supersede." Aguilar, The Spirit of Judaism, 227-229.

59 "Others again, earnest in the cause, yet mistaken in the means, search and believe the writings of the Rabbis, take as divine truths all they have suggested, and neglect the Bible as not to be compared with such learned dissertations. And why should this be? Why should the Bible be shunned by that people, to whom it was so peculiarly intrusted? [sic]. . . Mournfully they err, who thus preserve the English Bible from the hands and hearts of their children [for fear of conversion in reading a Christian translation]. It is this great error, which prevents the spirit of piety from taking possession of the heart, and binds us to cold and lifeless forms; it is this which is the real cause of so many Israelites having embraced Christianity." Ibid., 52-54.
} 
of Judaism, which was also vehemently anti-Talmudic. ${ }^{60}$ Aguilar's protestation that her vision of a biblical Judaism would prevent conversion might appear to undermine such an interpretation, but it certainly failed to convince many of her contemporaries otherwise. ${ }^{61}$

A little earlier we saw how the biographical sketches in Women of Israel could be understood as a platform upon which Aguilar sets out her vision of ideal womanly spirituality. But Aguilar claimed that it was also very important to her that her Jewish contemporaries did not have to look to Christian moral literature or religious commentary for such guidance. She was determined that there should be no necessity for Christian writings to "make Israel spiritual." ${ }^{22}$ One way to avoid this was to return to the Divine Word. As she put it, "[T] he Bible must become indeed the book of life to the female descendents of that nation whose earliest history it so vividly records. . ." ${ }^{63}$ In drawing upon the Bible, primarily, she sought to generate a set of edifying lessons for her community that was entirely dependent on Jewish sources. With examples such as Deborah, Women of Israel aimed "to prove that we have no need of Christianity, or the examples of the females in the Gospel". ${ }^{64}$

In the fictional series of letters collected together in The Ferwish Faith, Aguilar continued with this theme, when, as the Sephardi matron Villena, she sought to convince Annie, the Jewish girl who was considering conversion, that the inspirational texts of promise, narrative and spiritual guidance, that sounded as though they belonged to the New Testament, actually belonged to their own Bible. ${ }^{65}$ At times, this was not always obvious, and it was often necessary to look beyond the surface meaning in the "search for divine lessons" ${ }^{66}$ Even so, she said,

\footnotetext{
${ }^{60}$ For an overview of the debate, see Daniel Langton, "A Question of Backbone: Comparing Christian Influences Upon the Origins of Reform and Liberal Judaism in England" in Melilah 3 (2004).

${ }^{61}$ In this context, the editor, Isaac Leeser, comments, "Again I must remark that Miss A. has relied too much upon the calumniators of the Jewish character as authority." Aguilar, The Spirit of Judaism, 52.

62 "With such [biblical] writings our own, and ours from centuries long past, do we need the works of Christian divines to make Israel spiritual?” Aguilar, The Women of Israel, 569.

${ }^{63}$ Ibid., 15.

${ }^{64}$ Ibid., 18.

65 "In the constant study of the Word of God, you will be very often startled to find that a similar style of promise, narrative, and spiritual guidance, which you thought were only revealed in the New Testament, were found in our's ages and ages before; and that it is our utter neglect and disregard of these precious things which has so concealed them, as to cause the supposition that they were given to the stranger rather than to us. . [Y] ou always supposed that they [comforting verses] came from the New, not the Old Testament, and were, especially, the privileged possession of Christians, as they were frequently quoted in Christian books, and those of your own people with whom you have ventured to speak on the subject, knew nothing about them. . [You have] sometimes found yourself longing to believe in the New Testament, parts of which, seemed so much more simple and clear than the [86] old." Aguilar, The Fewish Faith: Its Spiritual Consolation, Moral Guidance and Immortal Hope, 40-41, 59-60, 85-86. Aguilar gave several examples. "'There is more joy in heaven over one sinner that repenteth, than over ninety and nine who have not sinned,' is a sentiment found in the Gospel; and therefore supposed to be the spirit of the Christian religion, [179] in contra-distinction to that of the Jew. But this, like many other similar assertions, is a great mistake. It was the essence of the Jewish religion first, and thence, and by fews, was preached to the Christians." She cites Rabbi Abraham Belaish (sic), 'Biblical Expositions', 44, 88. Aguilar, The fewish Faith: Its Spiritual Consolation, Moral Guidance and Immortal Hope, 178-179. Abraham Belais (1773-1853) was a Tunisian rabbi with a history of financial mismanagement who spent time in Algiers and Nice before arriving in London in 1840; he published Biblical Expositions himself in 1844 in Hebrew and English.

${ }^{66}$ In the context of immortality and Elijah's ascent, which reminds those who suffer that 'their souls were deathless, and their dwelling was above', she writes, "Do not regard this rendering of the translation of Elijah as the mere dream of an enthusiast, dearest Annie. The word of God is granted us to be our guide, not merely by precept, but by examples - not only by revelation in direct words, but by analogy. We are to look upon all it records as instruction, and search for divine lessons, not be content with merely those which lie upon the surface." Aguilar, The Fewish Faith: Its Spiritual Consolation, Moral Guidance and Immortal Hope, 360.
} 
We must remember the Old Testament is OURS. That of the glorious truths it reveals, and the precepts it bestows, no-one can deprive us, unless we disregard them ourselves, and by indifference and neglect, permit others to think that we have neither right nor interest in them. ${ }^{67}$

Villena/Aguilar observed with some pleasure that modern expressions of Judaism were increasingly dependent upon the bible, suggesting that erroneous teachings would soon be a thing of the past ${ }^{68}$ for, she said, the Talmudic sages had never intended that their ingenious commentaries would have taken the place of the Word of God. ${ }^{69}$ The same would be true of contemporary un-biblical hopes such as the much-discussed Jewish return to Palestine. ${ }^{70}$ There was a dire need for religious, edifying literature for Jewish women in the English vernacular, ${ }^{71}$ for whom the wisdom of the Jewish sages was impossible to master. (It is interesting to hear a sense of regret in this observation). ${ }^{72}$ And although many other modern

${ }^{67}$ Ibid.

68 "That the doctrine [of transmigration] may be found in the writings of the Hebrews is very probable; but it must be found in the Bible to be Judaism." Ibid., 275. "That there may be in certain portions of our theological works in which the Jewish doctors of the early ages wrote such an idea as Milton embodied in his 'Paradise Lost,' [i.e. 'the Christian doctrine of heaven and hell, Jesus and Satan'] with the exception of Jesus, as some Christians assert, I cannot deny; for I am not acquainted with the deep Jewish works in question. But even if it did, their opinions can no more be adopted as articles of belief than the poem of Milton for the New Testament gives no more foundation for the latter than the Old for the former." Aguilar, The Fewish Faith: Its Spiritual Consolation, Moral Guidance and Immortal Hope, 435-436.

69 "The ancient sages, whose notions we have been considering [in the context of outlining how the four elements, earth, fire, water, air, are representative of characteristics that make up a man], used both their capacious intellect, and their peculiarly vivid imagination, in illustrating certain simple texts, so as familiarly to instruct and delight the masses of their countrymen. They never intended these various illustrations and commentaries to take the place of that venerable Word, which was their foundation, but merely as an intellectual exercise to amplify and define." Aguilar, The Jewish Faith: Its Spiritual Consolation, Moral Guidance and Immortal Hope, 57. Aguilar's chapter on spirituality was highly dependent on the four sermons of Abraham Belash (sic), concerning earth ('which, they say incites to indolence and laziness in work' 55), fire ('incites pride, overbearing, haughtiness, wrath, envy, jealousy, covertousness and ambition' 54), water ('incites to mercenary craving for worldly treasures and pleasures' 55), and air ('tends to all those petty levities and abuses of speech' 54). Ibid.

70 "Palestine, struggled for by Christian and Mahometan (sic), and still lying waste, as the Lord ordained, giving not to strangers the fruition, and the beauty, and luxuriance, which were given, and will again be given, to the Jews: - Palestine, still regarded with an eye of longing by the true Hebrew, as his only home; by the Christian as indissolubly linked to the Past, - is not Palestine itself, then an evidence of the truth of revelation. . . ?” Ibid., 127. "I am aware, that many amongst us, and even amongst Christians, imagine that the repeopling of Judea, will be accomplished naturally (so to speak); and occasional efforts have been made, and pamphlets have been written, to manifest the wisdom of a co-operation of certain nations, or promulgation of certain statutes, compelling or holding out rewards and privileges, for the Jews to return to Judea: but to my feelings, these efforts are utterly useless. It is impossible to read the Prophets with any attention, and not to perceive, that our return will be attended by miracles yet more stupendous than those which marked our progress from Egypt; by a regeneration of the heart, and annihilation of all inclination to sin, which, in the present state of man, is impossible; and by the resurrection of the dead, which will not be till the end of days 'when the sun shall not give light by day, nor the moon by night, but the Lord shall be thine everlasting light, and they God thy glory. // Our promised restoration, then, is a confirmation, instead of a denial of our soul's immortality; for every reference to it marks the triumph of the spiritual over the merely corporeal, and this in itself is proof of our mingled nature, and of the continued existence of the spirit, however the body may lie in corruption. . . Such and such alone, is the promise attendant on our restoration; and how shall we call this temporal greatness and human subjection of the nations? Dearest Annie, banish the mistaken thought. It has no foundation in our Scriptures; therefore it is wrong, and has no part in Judaism." Aguilar, The Jewish Faith: Its Spiritual Consolation, Moral Guidance and Immortal Hope, 367-368, 369.

71 "To women especially, a religion in which love is the vital essence, is imperatively needed. And, therefore, am I so earnest in endeavouring to display its true spirit to you." Aguilar, The Fewish Faith: Its Spiritual Consolation, Moral Guidance and Immortal Hope, 83. It was the editor of The Spirit of Judaism, Isaac Leeser, who fulfilled this call, publishing the first Jewish translation of the Bible into English in 1845.

72 "For them [our FEMALE YOUTH], there is literally no help in the way of vernacular religious literature. For our young men, there are the works of ancient sages; there are ministers and teachers to instruct in their obsolete 
authorities had proved a bitter disappointment, ${ }^{73}$ Villena/Aguilar had found inspirational the bibliocentric Reform minister David Woolf Marks' attempt to reconcile the threat of the law with the comfort of the prophets. ${ }^{74}$

So, what can we say about how Aguilar orientated herself to her faith's sacred writings? Certainly, she repeatedly claims to have founded her faith upon the Hebrew Bible, of which she wanted a Jewish translation into English, and thus she regards the Talmud as a very secondary text, quite unnecessary for appreciating the true essence of Judaism. In this context, her attitude towards Christianity once again appears torn in two directions. On the one hand, she remains vocally opposed to conversion, determined to offer Jewish alternatives to Christian devotional literature and to reaffirm the Old Testament (rather than New Testament) origins of so many spiritually uplifting texts. On the other, despite an occasional note of regret that she was denied access to the wisdom of the rabbis, she appears to have internalised the anti-Talmudic critique of contemporary Evangelical Protestant Christians along with their conviction that the bible was the sole authority.

\section{(iii) Relating to the Community in terms of both fews and Christians}

In The Spirit of Judaism Aguilar had argued for the need to stress spirituality over the external forms that characterized much of Judaism as she found it, and had denigrated rabbinic learning insofar as it distorted the pure teachings of scripture. In so doing, she was redefining what constituted an authentic Jew. But in this theological work she also sought to redefine the relationship between Jews and Christians or, at least, between those Jews and those Christians who she believed shared common religious sensibilities. There were undoubtedly serious doctrinal issues on which Jews and Christians could not agree, such as the Jewish concept of the unity of God as taught in the Shema,$^{75}$ or the Christian need for a saviour which resulted in them seeing "our beautiful law as one of fire and blood". ${ }^{76}$ But Aguilar was primarily concerned to stress the common religious outlook. She observed that many Protestants were philo-Semites who believed that the restoration of Israel was connected with their final redemption and who looked at the Jews with a mixture of admiration, awe and love. ${ }^{77}$ She

\footnotetext{
and difficult languages, and explain their often puzzling and metaphysical sense. There is a vast fund of Hebrew learning and theology open to them. Their larger intellect, deeper reasoning, greater intensity and power of concentrating thought, will enable them to enter into, and master them; but this to woman is utterly impossible. Destined for home and home duties; to enliven and rejoice all members of the home, be they parents, brothers and sisters, husbands and children." Ibid., 8-9. Traditional authorities mentioned by Aguilar included sages 152-3, Joseph Albo 156-158, Maimonides 202, 209, 228, 230-, 429.

${ }^{73}$ Regarding Mendelssohn's Phaedon (1767), she wrote,"[T] he feeling of disappointment with which I laid down the book was absolutely painful. There was no evidence of the Hebrew within its pages; the follower of any creed might have compiled it. It could not teach the Christian the immortal hope and spiritualised faith of the Jew. .." Ibid., 423.

74 This was second-hand knowledge, Aguilar commenting, "I do not know the exact words, not having heard, or read his sermon." Ibid., 193.

${ }_{75}$ Aguilar, The Spirit of Fudaism, 4-7.

${ }^{76}$ Aguilar discussed at some length the Christian need for a saviour in contrast to the Hebrew creed - "one of the great distinctions between the Hebrew and Christian" - and of the law - "They look on our beautiful law as one of fire and blood". Ibid., 219.

77 "Do not the enlightened and earnest members of the Protestant church all acknowledge, their final redemption will be, in some way, connected with the restoration of Israel? Do not the truly religious of all sects look upon us with feelings near akin to admiration and awe, ay, and even love?” G. Aguilar, The Spirit of Judaism (1842), 16.
} 
could readily sympathize with their spiritual concern for those trapped within loveless, lifeless traditional forms of Judaism, asking "Why should we so condemn the[ir] custom of seeking converts?. . Why should we be angry with the[ir] wish to lead us where these blessings are supposed to be found?" 78 Between a true Christian and a true Jew the points of agreement were many, and the differences, however important, were few and "need never be brought forward". ${ }^{79}$ The similarities were only natural, for, as we have seen, the source of their knowledge of the God of love was the shared text of the Old Testament, ${ }^{80}$ from which the simplified New Testament with its much-lauded ethics was derived. ${ }^{81}$ She therefore condemned those Jews who misrepresented Christianity, just as she did those Christians who misrepresented Judaism. ${ }^{82}$ For this reason, and adopting the opposite position to that presented in Women of Israel, Aguilar argued that the Jew could and should profit from the wealth of Christian devotional resources.

$[T]$ here are many, very many excellent aids to the spirit of religion found in books written indeed for Christians. . . Why should we be startled at selecting portions [for laudable employment] from Christian authors? The morality they inculcate, the spirit they breathe, come from the fount in which they both believe, the Old Testament. ${ }^{83}$

Likewise, she argued that Jews might profitably emulate the evangelical practice of identifying fulfilments of biblical prophecies as proofs of their own faith. She writes,

The Christians seize with avidity the fulfilment of the prophecies, particularly those relating to Edom, Egypt, Moab, Ammon, Palestine itself, as proofs and evidences of the truth of their religion. How easy it would be to select portions from these very books for the instruction of our children; for the fulfilment of these prophecies only proves the truth and eternal nature of our law, of the whole Book of Life, according to our belief. . . Proofs of the truth of Christianity are to the young Hebrew, proofs of the truth of Judaism. Conversion cannot take place on either side; but mutual esteem and charity will take the place of such desire; for if both religions appear to have the same foundation, it is evident God alone in His own good time can remove the veil which each believes flung over the other. ${ }^{84}$

${ }^{78}$ She went on: "Why should we so condemn the [Christian] custom of seeking converts? If but to too many the Jewish religion is allowed to bring no comfort, no devotion, no spirit, and it is from those misguided ones, the whole religion is regarded; why should we be so angry with the wish to lead us where these blessings are supposed to be found. If there be aught to condemn, it is the lukewarmness and ignorance of those of our own people, who declare there is no comfort, no spirit in their faith. .." Aguilar, The Spirit of Fudaism, 22-23.

${ }^{79}$ She continued: "[T] he points of agreement are many, so many that our conversation might ever be of our mutual Father which is in heaven, of His glorious works, and attributes and love - [as] though that in which we differ never mingled with it." Ibid., 23.

80 "This is the God the Nazarene [i.e. Christian] emphatically calleth love; this is their God and OUR God, for it is from us - from us alone - that they have learned in part to know Him." Ibid., 36.

81 "Why do we only too often hear even amongst professing Hebrews, that the morality of the New Testament infinitely surpasses in beauty and charity that of the Old?.. [T] he whole system of morality preached by the founder of Christianity is that, in which WE were instructed by God Himself, either in direct communion with Moses, or through His chosen servants the prophets! Its only change is from the lofty language of inspiration which the chosen of the Lord alone could be supposed to understand, to the brief and simple phrases better suited to the comprehension of the heathen to whom it was addressed. . . [S] hall we declare the Christian Ethics are the best, when we know nothing, seek to know nothing of our own?" Ibid., 54-56.

82 "This [making manifest the spiritual beauty of Judaism] would be evincing our love to our universal Father, and our desire to exalt His glory, much more to the improving of our own hearts, and to the enlarging of charity towards our fellows, than the endeavour, too often made in scorn and hate, to found the truth of our own belief on the falsity and degradation of the Christian." Ibid., 88.

${ }^{83}$ Ibid., 102.

${ }^{84}$ Ibid., 162-163. 
In this passage we are reminded that while Aguilar certainly disapproves of conversion, yet she clearly believes that the common biblical foundation of both religions belied the differences that each saw in the other. It is entirely possible to read The Spirit of Judaism as an impassioned plea for Jew and Christian to recognise himself in the other; and to see that the biblically-based spiritual Jew shared more in common with the biblically-based spiritual Christian than either did with formalists in their own camps. Likewise, in a work of historical fiction, Records of Israel (1844), Aguilar puts the case that Christians have unfairly failed to interpret the historical persecution of the Jews in the same way as they do persecution of their own members, namely, as "proof of truth, fidelity, and divine support". ${ }^{85}$ The two romantic tales concerning the Jewish expulsion from Spain in 1492 and the troubled lives of crypto-Jews in Lisbon in 1755, were fictional narratives designed, she said, "to bring [this] historical truth more clearly forward." 86

In Women of Israel, this interest in identifying one's true community is played out in a female-only environment. In the introduction to this extended meditation upon the individual experiences of Jewish women, ancient and modern, she was certainly prepared to take issue with some female Christian authors. These, she said, had misrepresented the ideal of true womanhood as a specifically Christian virtue. ${ }^{87}$ In particular, she took exception to the role they gave to Christ in their construction. Their works, which, like her own, sought to draw inspiration from the lives of biblical women, were written for the Christian world and, as she put it,

Education and nationality compel them to believe that 'Christianity is the sole source of female excellence'. . . nay, more, that the value and dignity of women's character would never have been known, but for the religion of Jesus; that pure, loving, self-denying doctrines, were unknown to women; she did not even know her relation to the Eternal; dared not look upon Him as her Father, Consoler, and Saviour, till the advent of Christianity. . . We feel neither anger nor uncharitableness towards those who would thus deny to Israel those very privileges which were ours, ages before they became theirs; and which, in fact, have descended from us to them. Yet we cannot pass such assertions unanswered. . ${ }^{88}$

Aguilar was concerned throughout to defend Judaism against the charge that it had degraded its women. She was not even prepared to accept that the Talmud had devalued women in any way, even though elsewhere she was quite keen to dismiss it. ${ }^{89}$ At one point she even reversed the charge, arguing

\footnotetext{
85 'The Edict; a Tale of 1492' and 'The Escape; a Tale of 1755'. In her preface, Aguilar writes, " [] f persecution and intolerance be always the signs of divine chastisement, how shall we account for the massacres and cruelties inflicted on the Protestants, and, in the early stages of supremacy, by them on the Catholics? Yet in both these cases, martyrdom has always been considered the proof of truth, fidelity, and divine support; the seal, as it were, to the divinity of the cause for which they suffered. Why, then, should not the faithfulness to a religion far more persecuted than any other in the world, be considered in the same glorious light when applied to the children of God?.. Yet who draws examples from the Jew?" Grace Aguilar, Records of Israel (London: J. Mortimer, 1844), vi.

${ }^{86}$ Ibid., viii.

87 "Female [Christian] biographers of Scripture have, we believe, often appeared; although the characters of the Old Testament are so briefly and imperfectly sketched, compared to those of the New, that little pleasure or improvement could be derived from their perusal." Aguilar doubts whether the writings of Sanford, Ellis, and Hamilton "with 'women's mission' marked so simply, yet so forcibly, in the little volume of that name" have done enough to teach women of every race and creed their duty. Aguilar, The Women of Israel, 10.

${ }^{88}$ Ibid.

89 "To the Gentile assertion, that the Talmud has originated the above-mentioned blessing, and commanded or inculcated the moral and mental degradation of women, we reply, that even if it did so, which we do not believe it
} 
We see no proofs of the humanizing and elevating influence of Christianity, either on man or on woman, till the reformation opened the Bible, the whole Bible, to the nations at large, when civilization gradually followed. If, then, the situation of even Christian women was so uncertain, but too often so degraded, for nearly fourteen centuries after the advent of Jesus, who His followers declare was the first to teach them their real position, was it very remarkable that the vilified and persecuted Hebrew should in a degree have forgotten his nationality, his immortal and glorious heritage, and shared in the barbarity around him? ${ }^{90}$

Aguilar thus reacted angrily to the implied claim that Christianity had a monopoly on spirituality and that it should serve as a model for Jewish women. ${ }^{91}$ Despite these reservations concerning Christian women's arrogance, however, Aguilar was inclined to see a good deal in common between her idea of true spirituality and that of many Christian women. She could speak of "the spiritual system common to Protestants and Jews," 92 and in terms of defining what she called "spiritual essence", she felt comfortable drawing upon a range of Christian women novelists to make her point. The work of one was described as "so essentially SPIRITUAL, that. . . we know it must be the religion of God's word". ${ }^{93}$ This attitude had implications for her fiction.

As we saw with Queen Isabella in The Vale of Cedars, Aguilar was quite capable of presenting a Christian woman sympathetically as a spiritual model in a Jewish historical romance. However, in several of her novels in which she is engaged in illustrating the spirit of true piety, Aguilar tells the stories entirely without reference to Jews or Judaism, the cast of characters being exclusively Christian. In the introduction to her best-selling novel Home Influence, which was published in 1847 (although written ten years previously), ${ }^{94}$ she acknowledged that some Christian mothers might be suspicious of her reputation as a Jewish author and "explainer of the Hebrew Faith". She was quick to appease them.

[The author] begs to assure them, that as a simple domestic story, the characters in which are all Christians, believing in and practising that religion, all doctrinal points have been most carefully avoided, the author seeking only to illustrate the spirit of true piety. ${ }^{95}$

does, its commands are wholly disregarded, and its abolishment [or replacement by NT] is not needed to raise the Hebrew female to that station assigned her in the word of God. . . If, indeed, there are such laws [of female degradation], they must have been compiled at a time when persecution had so brutalised and lowered the intellect of man, that he partook the savage barbarity of the nations around him, and of the age in which he lived. .." Ibid., 11.

90 Ibid., 12.

91 Elsewhere she wrote of the tendency of so-called "universalist" Christian literature to be prejudiced against Judaism, "infused" as it was with Christian doctrine. Cited in Scheinberg, Women's Poetry and Religion in Victorian England: Jewish Identity and Christian Culture, 150.

92 "Let me repeat, and enforce the repetition, that by the spiritual system common to the Protestants and Jews, I do not in the very least allude to doctrinal points, for in our articles of creed we are utterly, entirely, and necessarily opposed; but simply, to the mutual belief in immortality, and that heaven is infinitely preferable to earth; to our mutually binding laws: 'Thou shalt love the Lord thy God, with all thy soul, and all thy might; and thou shalt love thy neighbour as thyself;' to both being commanded to practice charity, modesty, humility, brotherly love, forgiveness of injuries, unquestioning faith, and child-like obedience. It would detain us too long to dilate on all the points on which we agree; points it would be well for both parties to ponder on more frequently, but which too often become invisible from the too often haughty arrogance of the Christian refusing us the very privileges, spiritual and moral, which he has derived from us alone." Aguilar, The Women of Israel, 560.

93 "Every single line by Mrs S.C. Hall. . . is so essentially SPIRITUAL, that without a single syllable unduly introduced of religion, we know it must be the religion of God's word, which is the mainspring of her being." Other female writers "in the same beautiful class" include Mrs. Howitt, Mrs. Southey, Joanna Bailie. Admired as moral, rather than spiritual writers are Miss Edgeworth and Miss Austin. Ibid., 570.

${ }^{94}$ Lask-Abrahams, "Grace Aguilar: A Centenary Tribute," 144.

${ }_{95}$ Grace Aguilar, Home Influence: A Tale for Mothers and Daughters (London: R. Groombridge, 1847), vii. 
This tendency to appeasement, the sense of a nagging fear of Christian disapproval, permeates a lot of Aguilar's writing. Her poem 'The Hermit', one of her earliest publications from a collection of poems entitled, The Magic Wreath of Hidden Flowers (1935), is but one example. In it she calls a friend to accompany her to "the old monk's cell", describing its ever-joyful occupant as "a good old man and kind." She confesses, "once I feared his shrouding hood, His strange coarse fashion'd gown" but, over time she has come to see that "now I find he is so good, I only fear his frown". ${ }^{96}$ Her feelings towards this romantic image of the Christian other whose inner spirituality cannot be denied, neatly captures Aguilar's own experience: her one-time fear of Christianity as a threat had long-since been replaced by her acknowledgement of its goodness and by her fear, rather, of its disapproval.

Aguilar's later devotional poetry was more ambiguous with regard to Christianity, however. In a poem entitled, 'A Visit to Jerusalem: While Listening to a Beautiful Organ in One of the Gentile Shrines' (1844), Aguilar turns on its head the traditional convention of reading Christian meanings into Jewish biblical texts and history. Ostensibly describing the Christian organ-music, priest's vestments, altar, and congregational worship, her use of biblical language and symbols transforms this Church service into the noisy, colourful ancient world of biblical Jewish celebration and spiritual ecstasy.

Methought the cymbals' sacred sound came softly on my ear,

The timbrel, and psaltery, and the harps's full notes were near;

And thousand voices chaunted, His glory to upraise,

More heavenly and thrillingly than e'en in David's days. (lines 5-8)

Methought the sons of Levi were in holy garments there,

Th'anointed one upon his throne, in holiness so fair,

That all who gazed upon him might feel promise be fulfill'd,

And sin, and all her baleful train, now he had come, were still'd. (lines 9-12)

My country! Oh my country! Was my soul so enrapt in thee

One passing moment, that mine eyes might all thy glory see?

What magic power upheld me there? - alas, alas! it past,

And darkness o'er my aspiring soul the heavy present cast. (lines 17-20)

I stood ALONE 'mid thronging crowds who fill'd the stranger shrine,

For there was none who kept the faith I hold so dearly mine:

An exile felt I, in that house, from Israel's native sod, -

An exile yearning for my home, - yet loved still by my God. (lines 21-24)

The poem can be understood on at least two levels. It could be read as a gentle swipe at the Christian tendency to think of biblical Judaism only in terms of how it prophesized Christian truths. By doing the reverse, by portraying the Gentile shrine as a type or shadowy representation of the glorious Temple, the Christian reader finds herself in unfamiliar, slightly uncomfortable territory, whereby the very conventionality of the supersessionist practice is subtly undermined. But one could as easily interpret Aguilar's last verses here to

\footnotetext{
96 "Oh come with me to the old monk's cell,/ He's a good old man and kind,/ And joy, though he will dwell alone,/ He ever seems to find./ Oh once I feared his shrouding hood,/ His strange coarse fashion'd gown;/ But now I find he is so good,/ I only fear his frown./ Come, Lucy, you who love to hear/ Old tales, or legends wild,/ He'll tell you many; do not fear,/ He loves a gentle child." G. Aguilar, 'The Hermit' in Grace Aguilar, The Magic Wreath of Hidden Flowers (Brighton: W.H. Mason, 1839).
} 
suggest that a glorious platonic reality lies behind the shadows of the humble Christian service, and that while, for a Jew, the spirituality of this lost, great world of biblical Judaism can only be occasionally glimpsed, it is not so very far away and might even be recovered by those with appropriate spiritual sensitivity, that even among the Nazarenes, one might say, this fragile flower of spirituality blooms. Thus the poem appears to reflect at the same time both antagonistic and sympathetic attitudes towards Christianity.

It is in The Jewish Faith, that collection of letters to Annie, a Jewish child who was tempted to convert following the loss of her family, that Aguilar wrestled most profoundly with the relationship between the two religions, and where we can find bound together many of her complex, even conflicting, views. The attractions to Christianity were many, it was admitted, including the comforting, ever-vaunted hope of a re-union with lost loved ones, ${ }^{97}$ the devotional literature that explained religion and gave strength and comfort in affliction, the apparent life of peace and happiness reflected in the enviable way in which certain Protestant families lived their religion in stark contrast to Jewish families. For example, she writes to Annie,

[W] hen I wrote to you in my first letter of the necessity, the strength and peace of religion, you had felt that, if you were a Christian, you might hope to experience all this, but that as a Jewess, it was impossible - that there were so many books, not merely to explain the Christian religion, but to give sympathy and comfort in every affliction - that there were churches to frequent, and so many home-speaking, heart-appealing prayers to help them to lift up their thoughts to God, that could you but be a Christian, you might be comforted, and even happy - that you have been tempted most strongly to adopt the Christian faith. . . [W] henever you asked any questions regarding religion, your friend had entreated you to seek information from your own - that in her family, as in other of your Protestant friends, religion was actually taught, made a rule for life, and you could not recall any Jewish family in which this was the case, even your own. . . I agree with you in the many and far superior advantages of the Christian over us [Jews]. Religious books adapted for our youth and sympathising in our feelings, we have not indeed. With the sole exception of one Synagogue in London, our houses of worship cannot be to our youth as the Christians' are to theirs. . .98

But such grounds, Villena/Aguilar argued, were not reason enough to convert, for the doctrine of immortality had been a Hebrew one before Christian, ${ }^{99}$ and it was not a Christian

\footnotetext{
97 " $[$ Y] ou cannot help sometimes drawing a comparison between the sentiments of your Christian and Jewish friends. In the one, the thought of belief in, Immortality seemed so ever present, that even the heaviest bereavements were soothed by the hope, not only of the happiness of those who were gone, but of an everlasting re-union; and, of course, Death lost its deepest horror: that amongst your Jewish acquaintance, it was a subject always shunned, the thought of immortality so vague and undefined, so little able to console in bereavement, so clothed in fanciful hypothesis, that it seemed to you, that it could have no solid foundation, and really was wanting in our religion. . . [Y]ou could neither think of those you had lost, nor of death, as it related to yourself, without a shuddering dread, which made you long to embrace the faith of Christians." Aguilar, The Jewish Faith: Its Spiritual Consolation, Moral Guidance and Immortal Hope, 226-227.

${ }_{98}$ Ibid., 32-33.

${ }_{99}$ In the context of her own experience of loss, she writes, "As if to tempt me from my sole Rock of help and salvation, the belief of the Christian came to me, as it has come to you, and promised comfort and redemption, if I would but accept and believe in the sacrifice of Jesus. So strong was the temptation, that I often think the sin of apostasy must have been mine, had not the infinite mercy of my God so blessed a mother's instructions, so as to lead me to His word for my sole guidance and relief. . I saw no need for embracing another faith, when the religion of my father gave me not only all I required both for heart and mind, but showed me that if I deserted that, I could not embrace the Christian faith, for all that the Christian's [sic] taught of death and immortality was the Hebrew's centuries and centuries before. . How then can we, dare we, by indifference and silence, by living as if we had no
} 
life which gave peace, but rather one properly centred on the Bible. ${ }^{100}$ More problematic was the fact that Villena/Aguilar was prepared to acknowledge throughout that, when it came to matters of spirituality, there was little to distinguish Christian from Jew. ${ }^{101}$ Why, then, concern oneself about the label? Why not convert? Her answers included loyalty to one's birthreligion, ${ }^{102}$ and the observations that spontaneous prayer was as Hebrew as it was Christian, ${ }^{103}$ that adherence to Christianity was no guarantee of spirituality, ${ }^{104}$ because the Christians were fragmented amongst themselves, ${ }^{105}$ and that many forms of Christianity suffered from superstitious teachings, too, which had nothing to do with the teachings of its founder. ${ }^{106}$ But in the light of her obvious high regard for Christian spirituality, none of these were terribly

thought or hope beyond this earth, give a colouring to the mistaken idea that all our knowledge of and belief in Immortality is derived, unconsciously to ourselves, from our intercourse with Christians; and that it forms, and formed, no part of the Jewish faith! How can Jew or Christian read the Old Testament, and yet read this?" Ibid., 270-271, 410.

100 " $[\mathrm{But}]$ it is not the actual creed which marks the difference in individuals or families. It is the study or neglect of the Bible. The spiritual, the consoling and strengthening piety to which you allude, as characterising your friend and her family, does not proceed from the fact of her being a Christian, but from her having made the Bible her sole rule of action." Ibid., 34.

101 "Ask any enlightened Protestant, and he will tell you that the actual doctrines of belief are of little moment, compared with the spirit which he supposes that doctrine breathes, and which the preaching of Jesus and his apostles diffused over a benighted world. And that spirit (but wholly and entirely distinct from doctrines, on the precise nature of which, not two congregations could be found to agree as early as the second century after its propagation) had its origin, its influence, its infallibility, in the wider spread and universal acknowledgement of that blessed Word, which for centuries before, for our especial benefit, God had inspired holy men to write." Ibid., 41.

${ }^{102}$ Ibid., 60. You will very probably ask me, if I consider all religions alike in the sight of our Father in Heaven and the earnest worshippers of each equally acceptable to Him, why I am so desirous that you should remain a Jewess. Because, dearest Annie, it is a widely different thing to be earnest and faithful to the creed we have imbibed from infancy, to deserting it, without examination, for another.

103 "[A]nd yet to bring up our petitions before God was not commanded in the Jewish dispensation, as in the Christian - was not taught in direct words, because it was already, and had been, from the time of Seth, the vital breath of those individuals from whom God's chosen race descended, and was by them, of course, transmitted to their sons and immediate followers. . . We have specimens of it ['its secret and individual practice'] from the king to the private female, from the law-giver to the captive, from Noah, and Abraham to Esther, Ezra, and Nehemiah; besides instances innumerable in the Psalms and Prophets; and who then can say, because there is no direct command to pray in the Old Testament, that it formed no part in the Jewish dispensation? / / In the New Testament, we find the exercise enjoined in direct words, 'pray always,' 'pray evermore,' 'pray without ceasing.' Too long petitions were justly rebuked and a model given, but why was this? Because the nations to whom Christianity was preached, as preparatory to a knowledge of the God of Israel, were sunk in ignorance and Heathenism." Aguilar, The Jewish Faith: Its Spiritual Consolation, Moral Guidance and Immortal Hope, 283.

104 "I am no Christian. Nay, I have been, the last four years associating with such unenlightened members of the Greek and Roman churches, that, had I been narrow-minded enough to judge only by them, the Christian would be to me but a term for superstition, irreligion, and utter ignorance of God's word, compared with which, the most ignorant of my own faith would seem infinitely superior. .." Ibid., 34-35.

105 "[W]ere your circle wider, you would find nominal Christians exceeding the number of nominal Jews, and so divided amongst themselves, that, were you really bent upon deserting your faith, which I do not believe you are, you would find it difficult to decide which of these various thinkers and speculators it would be safest and best to join. I do not write this from any feeling of disrespect or uncharitableness: as conscience dictates, so it is right to worship; and if our Father in Heaven looks with an eye of love and has compassion on all His creatures, bearing with error itself in the mode of service, for the sake of the love and zeal borne towards Himself, how dare we, weak, finite mortals of a day, judge harshly of one another?" Ibid., 60.

${ }^{106}$ Aguilar argues that the fact that some Jews believe in transmigration "no more interferes with the purity and holiness of Judaism, than the strange and childish superstitions of Romanism have to do with the religion of the true Christian. . . The Romanists believe in purgatory, and the efficacy of masses for the dead,. . . visionary ideas ... which Jesus did not teach.” Ibid., 272, 274. 
convincing. And Villena/Aguilar admitted as much when she said that if Annie could not be satisfied with Judaism, then she would not hold her back from conversion. ${ }^{107}$ Aguilar's position seems to have been a ready acceptance that Anglo-Jewry was in a poor, lifeless state, but she remained convinced that there was no need for the spiritually-minded to lose hope and abandon their ancestral faith. What was required was the re-vitalisation of Judaism. To achieve this, one needed to return to the Bible, of course. But another effective means was to learn from the example offered by spiritually-minded Christians.

Villena/Aguilar develops in The Fewish Faith a theory of Christianity that could be reconciled with Judaism and valued positively. Christianity was a part of God's providential plan for the nations, fulfilment to a promise made to Abraham that "In thy seed all the nations of the earth shall be blessed." Jesus had been a Jew whose followers had taught the Gentiles the knowledge of the Lord and the Moral Law in "simpler words". ${ }^{108}$ Consequentially, she rejoiced at the efforts of "those noble and pure-spirited" Christian missionaries who brought "some knowledge of the divine commands. . to benighted lands". ${ }^{109}$ Of course there were enemies among the Nazarenes, who had forgotten the debt they owed Israel, ${ }^{110}$ but where Christians dedicated themselves to the Bible, there had been less persecution of the Jews. ${ }^{11}$ And, undoubtedly, certain doctrinal differences, such as the Jewish

107 "If, when you have stated every doubt and prejudice, my answers fail to make manifest the fullness, and the comfort, and the beauty of our spiritual faith; if, after due and patient examination, your heart and mind shall decide in favour of the Christian, I will not keep you back, grievous as it would be that so wide a barrier was flung between us." Ibid., 61.

108 "Even by the most prejudiced of our opponents, it is acknowledged, that Jesus was himself of a Jew, and his Apostles taught the Gentiles, in simpler words, the knowledge of the Lord, and of the Moral Law, already revealed to us. From us, then, the blessing of revelation certainly came, whoever might be the ministers to bear it, mingled with some human error permitted for a time, over the known world. "In thy seed all the nations of the earth shall be blessed,' God said to Abraham centuries before the advent of Moses; and in our dispersion, in the wider spread of OUR scriptures, in the immortal hopes, and glorious future destiny they reveal, in the ennobling aspirations they inspire, in their very revelation of a Father, who has dearer and tenderer, more enduring and more forebearing love, than any earthly parent, - I know this promise also fulfilled, and, in the revelation vouchsafed to the seed of Abraham, every nation blessed?" Ibid., 104-105.

109 "I do indeed rejoice, when I hear of the efforts of those noble and pure-spirited men, whom the world so often deride and contemn [sic], the missionaries, who seek to preach even their gospel to benighted lands, and so win them to some knowledge of the divine commands. I know that many would loudly condemn this as an entirely anti-Jewish idea: but believing as I do, and as my Bible authorizes me to believe, that all the present systems of Revealed Religion are working God's will, and gradually bringing nearer that glorious day, when all darkness, all error shall be removed, and when, our chastisement being ended, we shall be restored to our own land, and all nations flow unto us, and acknowledge with us that God is One: and believing, too, that unless the earth is brought in some degree to know God, this will not be accomplished - I must rejoice at every effort (be it of individuals or nations) to remove ignorance and reveal the Bible, or (as in the case of the Koran) some part at least of Revelation." Ibid., 160-161.

110 "I have already called your attention to the principles of the two great systems, Christianity and Mahomedanism, which, grafted on the Mosaic revelation, have been permitted to spread over the earth, as to forget their [Jewish] origin and believe in individual infallibility; and in the utter rejection of that people and that law, without whom both systems must fall meaningless to the ground." Ibid. 69.

111 "Of course there are exceptions to this fearful treatment of a people [constantly endeavouring, but without success, to vilify and exterminate the Jews], for whom those moral laws [contained in the Word of God] were compiled, and to whom that pure knowledge of the Lord was given, from which all nations and all people benefit. The more the Bible, the whole Bible, is made the guiding star of the land, and the Old as well as the New Testament studied, the more consideration the Jews receive, the less we read of persecution." Ibid., 96. 
insistence on God's unity, ${ }^{112}$ and the Christian insistence on original $\sin ^{113}$ and on the meaning of sacrifice, ${ }^{114}$ had to be maintained. But the only criteria that really mattered, she maintained, were those of "feeling" rather than of "doctrine", ${ }^{115}$ for both systems ultimately upheld the same moral truths and principles. ${ }^{116}$ There was therefore no need to convert these fellow "heirs to Immortality" to Judaism. ${ }^{117}$ Despite their differences, her attitude was manifested in the exclamation: "I respect, from my very heart, the true spiritual believing

112 "Christianity, again, approaching infinitely nearer to us [than Mahomedanism], in its spirit and its laws, and acknowledging the same guiding books, and therefore the same God, far advanced as she is in spirituality and enlightenment, and in holding forth many a bright example to us, of true and beautiful piety still, even she cannot embrace the doctrine of the one sole indivisible God, cannot realise the perfection and unity of His attributes, without the intervention of a mediator, and a holy spirit, distinct from, yet unified with Himself. It often appears strange, that where we have so much, so very much in common, the Christian idea of the Godhead should be so distinct from that of the Hebrew; that where a religious system has advanced so very near the sublimest truth, it should yet pause, incomplete, and present a stumbling block, which the enlightened Jew can never over-leap. It would appear still more strange, if I did not firmly believe it ordained in fulfilment of that word, which has declared, we should be a distinct people for ever, and which (humanly speaking) would be still more difficult of accomplishment, if the Christian idea of the Eternal were in all points like our own." Ibid., 67.

113 "The Christian creed is, that not only did Adam's sin bring death into the world, but condemned his own soul and that of all his unborn descendents, even the spotless babe, to everlasting perdition; that man has no power whatever in himself to pursue the good and strive for Heaven; that unless baptised, and so, through his sponsors, receiving Jesus, he is lost eternally; that only the acknowledgment of the Infinite Atonement can bring salvation; and without such acknowledgement, every effort after righteousness is futile, and the most earnestly pious lover of God and man condemned, without hope of redemption or escape; while the greatest and most impious sinner may be saved, if he only declare his belief in Jesus. I do not tell you this is the belief of all Christians. I know many who would shrink from it; but it is undoubtedly the general doctrine of Christianity, and so accounts for their anxious desire to convert all people to the same saving creed. . You see, then, though the groundwork of both faiths is the same, the superstructure is very different, and ought to be clearly defined to every young Hebrew. The Christian believes that every thought and act of man is clogged with sin. The Hebrew cannot believe so; because his Bible tells him, that there are thoughts, actions, ay, and even feelings, which are pure, and holy, and acceptable to his God." Ibid., 186-187, 190.

114 "This is the grand distinction between the Christian and Jewish ideas on the subject of sacrifice. The former, regarding their every mention in the Old Testament as types of the great sacrifice on which their faith is founded, must consider them of such primary importance, that all heart worship was imperfect without them. The latter, on the contrary, are taught, both by their Law and their Prophets, that they are merely secondary: but part of the outward and ceremonial rite, which was of no merit or importance whatever in itself, and by itself, but was accepted as obedience, or rejected as abomination, according to the inward spirit in which it was offered." Ibid., 221.

115 "I am quite aware, that the assertion of similitude between religions, whose doctrines of belief are so opposed, would meet with violent opposition, from many who term themselves orthodox Hebrews; but opposition will not alter truth, and I am ready to agree with them that between the formalist and the spiritualist, there is indeed a barrier which can never be passed; but this holds as good between Jew and Jew, Christian and Christian, as between Hebrew and Protestant. It is not the doctrines, but the feelings which are so impassably opposed. I would not check your intimacy with any Christian friend." Ibid., 31-32.

116 "Christianity in all, save its actual doctrine of belief, is the offspring of Judaism; and as one of our most enlightened and purest feeling Divines very lately said, 'The differences between Christianity and Judaism, however great and weighty in their speculative doctrines, disappear in the moral truths and principles alike upheld by both.' And the more we know of each other's faith and practice, the more clear and striking becomes this fact." Ibid., 12-13. The reference is to Rev. M.J. Raphall, Jewish Chronicle of 9th January, 1846.

117 "We have no need to make converts. We are, indeed, the first-born, first-beloved; but all who look to Him, and love God, according to the law they follow, are our brothers, and equally with us heirs of Immortality! We do not believe that God has mercy, and has opened the gates of His Heaven to the Jews alone. You will, no doubt, often be told by the nominal Jew, as well as by the nominal Christian, that this is only an individual, not a ferwish notion; but do not let your faith be shaken by such remarks. Our Bible tells us, that the law of Moses is incumbent on the Jews alone, not on the nations; and our ancient fathers (men with deep learning and profound wisdom, who of the present day can compare?) have told us in clear and simple words, 'The RighteOus AMONG The nations OF THE WORLD HAVE A SHARE IN THE WORLD TO COME.'” Ibid., 158, 162-163. 
Christian". ${ }^{118}$ This vision of Christianity helps account for why Villena/Aguilar encourages her young protégé to maintain close relations to her Christian friends, telling her to ignore the gossip of Jewish observers because there was no reason to fear conversionary efforts from a "true and enlightened Protestant." 119 It was true that Anglo-Judaism was in a poor state but this had nothing to do with exposure to its Christian surroundings. ${ }^{120}$ Quite the reverse Anglo-Judaism was lagging behind Anglo-Christian spirituality and intellectuality. ${ }^{121}$ Therefore it would do no harm and much good if the girl was to draw upon Christian devotional literature, for example, ${ }^{122}$ for a thorough grounding in one's own religion would keep one alive to the rare possibility of confusion of doctrine. ${ }^{123}$ Annie would be spiritually uplifted, and should not be afraid. As she explained,

Till that is obtained [i.e. Jewish spiritual literature is published], if we would seek aid for serious

thought, we must go to Christian books, choosing, of course, those which are more spiritual than

118 "Remember, I do not wish to touch on the Christian faith as regards themselves. As I have said repeatedly, I trace the workings of the Eternal in its progress, as a preparation for that great and glorious day when we shall all know Him. I respect, from my very heart, the true spiritual believing Christian. I only wish to make it clear to you, why, as children of Israel, neither you nor I could accept the first grand doctrine of the Christian faith [i.e. sacrificial atonement]." Ibid., 209.

119 "Not thinking very deeply, they [the only Hebrews you have known] imagine it quite impossible for any serious Christian, to take an interest in a young Jewess without desiring her conversion; and that Hebrews and Christians may have much, very much in common; that the very link between them may be religion, entirely and wholly distinct from the doctrines of creed, is so utterly incomprehensible, that they not only disbelieve in its possibility, but are always looking for some ulterior motive. I have no such feelings. No true and enlightened Protestant, ever yet descended to the petty and wicked meanness, of tampering with the faith of a young and almost friendless girl as yourself. Mistaken zealots there are, indeed, who deem the attempt to convert the most meritorious act they can perform; but these are seldom found among calm, enlightened Protestants. Know your own religion well, observe it from mental as well as loving conviction, and you will find yourself and your faith too truly respected, ever to fear even an attempt at conversion. [As if to a Christian audience:] It is the mere formalists amongst us, who have thrown such odium on the Jewish faith; but you must not judge the whole nation by the few with which you are thrown." Ibid., 30-31.

120 "I am aware that it is said repeatedly, that the Jews of England cannot feel as the Jews of former times; because they must have imbibed, from association with Christians, so many of their religious ideas." Ibid., 418.

${ }^{121}$ Aguilar admits, "we are so far behind our Christian brethren in spiritual and intellectual religion." Ibid., 445.

122 "Our huge tomes of Hebrew wisdom and learning are inaccessible to woman. . [But] All she requires, is to understand the unspeakable comfort, and the religion she follows, so as to obey its dictates from the calm conviction of the mind, as well as from the heart. Many suppose that this comes intuitively, and requires neither instruction nor sympathy. It may be for some: but the generality of our youth demand it, yearn for it with such an intensity of longing, that, finding no books of their own, they are compelled to seek the works of Christian writers - and then we are astonished, if they are more Christian than Jewish in their thoughts. A charge, by the way, incomprehensible to us individually, as we know not, and never could discover, the distinction between Jewish and Christian spirituality, on which some good, but prejudiced persons, lay so great a stress. The distinction of creeds is, indeed, very clearly to be understood and defined, as also the difference in their respective ordinances and modes of thought; but spirituality is common to every creed and to every nation who earnestly seek to know and love the Lord, according to the dictates of the Laws that each believe that He has given, and so observe. And if this be the case with every creed, how much more in common ought those to have, who acknowledge the same Book, and the same foundation? / But if the imbibing of Christian spirituality will do our young sisters no harm whatever, for it is Jewish spirituality as well, the imbibing of the peculiar creed of the Christian undoubtedly will, and this is the great evil to be counteracted in the indiscriminate perusal of Christian books." Ibid., 9-10. In addition to the Gospels, other Christian sources cited by Aguilar included Thomas Carlyle 75, Humphrey Davys 89-90, Gibbon 127, and Rev. Robert Anderson's of Trinity Chapel, Brighton, 340.

123 "From having no serious books of our own, fitted for our females and youth, those who are inclined to serious reflection, are compelled to turn to works, by serious Christian authors. There they will find sympathy and pleasure, but so intimately mingled with the peculiar bearing of the Christian faith, that unless fully and thoroughly versed in our own, it is next to impossible not to share the writer's belief in the excellence of his own religion, over and above that of any other." Ibid., 40. 
doctrinal. The spirit of the Christian religion is equally the spirit of the Hebrew; for both owe their origin to the same Bible. We have but clearly to understand our own, and a glance will divide our doctrinal points from theirs. Nay, more, you will find, the more you study and examine your own, that the very books which confirm Christians in their faith will confirm you in yours. One especially, a very beautiful work, 'Keith's Evidence of Prophecy,' was once lent me, not with any wish for its religious doctrines to convert me (that I knew from the upright character of the lender), but for the exquisite beauty of its language and sentiments. It is many years ago, for I was scarcely older than you are now, and just beginning to think for myself. Well do I remember the trembling with which I began its perusal - trembling lest my dawning hope and trust should be shaken by this Christian book. But both were strengthened, dearest Annie. It was a strange, an almost indefinable effect; but so it was. Every evidence of prophecy fulfilled, proved so convincingly that others were still to be accomplished; and the truth, the perpetuity, the unchangeableness of my holy faith, the impossibility of its ever merging into another, stood before me clearer and more convincingly than had ever done before. I have no fear of you perusing similar works. ${ }^{124}$

Nor should she concern herself with those who were suspicious about the influence of Christianity in this construction of a spiritualised Judaism. ${ }^{125}$ Those who denied such a thing only strengthened the hand of Christian critics who regarded Judaism as unspiritual. ${ }^{126}$ This account, synthesized from the letters, is as close to a coherent theology as we are likely to find. And yet it remains riddled through with problematic aspirations.

In discussing Aguilar's sense of community, one is impressed by her conviction that it was entirely possible to learn true spirituality from the lives and actions of Christians, both real and fictional. She is remarkably sympathetic to the attraction of Christian life, and readily acknowledges the spiritual poverty of contemporary Anglo-Jewry. By emphasising a shared community of spiritual Jews and Christians, she can explain why there is no need to convert each other. Arguably, she was defining her community in spiritual terms to include many among the Christian faith. And yet the ambiguity remains. Aguilar insists, of course, on

${ }^{124}$ Ibid., 144-145. Aguilar is referring to Alexander Keith's Evidence of Prophecy (Edinburgh: Waugh \& Innes, 1823), which aimed to support the truth of Christianity by demonstrating the historical fulfilment of biblical prophecies; of less interest to Aguilar was Keith's argument for a restoration of the Jews to their ancient homeland.

125 "But what can we say for those who amongst themselves can assert any thing so absolutely and scripturally, and even talmudically false, as the non-spirituality of their thrice holy faith? It is to me so marvellous, so incomprehensible, that any Jew can read his Bible, and its commentaries by many of our earliest sages, and yet believe this, that the only possible way to explain it, is the supposition that he actually cannot know the meaning of the word spirituality; and, by a strange mystification of ideas, associates it with the mere doctrines of Christian creed, particularly that of the 'Holy Ghost' and so rejects it as anti-Jewish, and tending to mislead him. This is the only tangible and rational reason I can find for this extraordinary error, which I have known take the possession of some minds so strongly, that the very word, 'spirit,' or 'spirit of God,' even in only a poem, terrifies from the perusal, or causes its condemnation as too Christian for the approval of any Jewish mind." Ibid., 52.

126 "Concerning this mistaken charge of non-spirituality in a religion which preceded from the mouth of God himself; that God whom we only know as SPIRIT, without form or substance, a pure essence pervading Heaven and Earth, and whom we are expressly commanded to worship in spirit and in truth, it seems to me that Christians have adopted and asserted it, simply from the mistaken supposition that we now receive and follow the ordinances of and superstitions of man, in lieu of the word of the living God. They suppose this partly from observation, and partly from the received, yet erroneous, assertions of books. Now, there is no such thing as ancient and modern Judaism. . . When our opponents bring forward the constantly reiterated assertion, that the Hebrews have mingled all sorts of petty and enslaving customs, and binding forms, which we cannot find in the Word of God, I answer, It is quite true; but human weakness and human error cannot tarnish the intrinsic beauty, nor interfere with the ordained perpetuity of the Mosaic system. And if we examine the origin of these human additions, we shall find they proceed from the intense desire of our ancient sages, to preserve the undying spark of religion alive within us by means of outward ordinances, which, by their constant occurrence, would bring our Creator to our thoughts, when, from slavery and misery, we were debarred from all more spiritual communion." Ibid., 46. 
maintaining the distinction between Jewish and Christian doctrines, even as she undermines these distinctions with her attempts to convince Christian readers of their shared worldviews. She suggests emulating Evangelical use of fulfilled biblical prophecy and she recommends the use of Christian literature, but also bitterly regrets the need to use it and denounces the Christian misrepresentation of the treatment of women in Judaism. She admires the morality and bravery of Christian missionaries but dismisses their New Testament as a simplified, compromised set of ethical teachings. Her poetry captures this ambiguity most perfectly, in the way it both emphasises the similarity of spirit, and at the same time subtly asserts Jewish superiority. It is as if she is always in a state of flux, moving between admiration and criticism of Christianity, often revealing an anxious hope of Christian approval.

\section{Conclusion}

Any attempt to define precisely how Grace Aguilar conceived the relationship between Judaism and Christianity is complicated by the fact that she was engaged in a one-woman programme of Jewish reform. It is not easy to define Christianity in relation to Judaism if one's view of Judaism is not yet fixed. It is even more complicated when one recognises that her reforming programme for Judaism drew heavily upon Christian influences. In this regard it is worth stressing her independence from the Anglo-Jewish Reform movement whose synagogue was established only seven years before her death. In sharp contrast to the London reform community, Aguilar stressed women's spirituality as the paradigm for a refashioned Judaism. Furthermore, while the first minister of the Reform Synagogue, David Woolf Marks, might have shared Aguilar's sensitivity to an Evangelical, bible-based, antirabbinic Christian critique of Judaism, and therefore also espoused a bibliocentric emphasis, he did not share Aguilar's sense of a shared spiritual community with, and her profound empathy towards, Christianity. ${ }^{127}$

Aguilar's particular interfaith project should be categorized as an 'appreciative relational theology' in that it sought to portray 'the other' in a way that encourages mutual understanding and respect. But Aguilar was more than simply a reform-orientated Jew with a burning desire to convince Christians of the respectability of Judaism. ${ }^{128}$ She was developing an ideological framework that aimed to prevent conversion and to justify why one should remain a Jew, that presented a robust critique of Christianity's distinctive doctrines, and that granted it a positive value-judgement, even to the extent of encouraging a sense of identification with, and emulation of, it. In this she was not entirely successful. Let

\footnotetext{
127 Although, it is worth noting that the co-founders of Anglo-Liberal Judaism, Claude Montefiore and Lily Montagu, did share this sense of shared spiritual community, however. See Daniel R. Langton's Claude Montefiore: His Life and Thought (London: Vallentine Mitchell, 2002) and "Piety, Tradition and Community in the Thought of Lily Montagu: An Anglo-Liberal Jewish Theology of Relation" in Women in Fudaism: A Multidisciplinary Fournal 7:2 (2010).

${ }_{128}$ Scheinberg argues, "Aguilar fervently believed that only through active 'defensive' engagement with Christian culture could Jews and Judaism advance in Diaspora life. . . If she sought strategies that could speak conclusively and inclusively to Christian readers, it was always part of a project of advancing Judaism and the Jewish people, a rhetorical strategy, I would argue, rather than an ideological commitment to Christian/Protestant doctrine." Scheinberg, Women's Poetry and Religion in Victorian England: Fewish Identity and Christian Culture, 154. Galchinsky notes that, officially, Aguilar adopted a neutral stance. But he points to her poor regard for rabbinic tradition. Galchinsky, The Origin of the Modern Fewish Woman Writer: Romance and Reform in Victorian England, $151 \mathrm{ff}$.
} 
us end now with a summary of the development of her theology in five stages. (i) Aguilar began with the desire to relate to Christianity in a positive way, which can no doubt be attributed to positive personal experiences in her youth and a growing sense of dissonance in seeing how each community tended to regard the other in wholly negative terms. (ii) Aguilar found herself re-assessing the assumptions that defined her own religious identity in exclusivist Jewish terms. Thus she recognised that neither Judaism nor Christianity could claim a monopoly over what she regarded as the essence of true religion, namely an emotive, romantic form of spirituality, which was to be prioritized over tradition. Likewise she acknowledged the shared claim to those sacred texts which she regarded as most authoritative, namely the Hebrew Bible. And in focusing upon the feminine perspective, she developed a sense of community that embraced a Christian as well as a Jewish sisterhood. (iii) As a result of her appreciation of Christianity, she committed herself to a process of reform: on the one hand, reform of Christian misconceptions of an authentic, spiritual form of Judaism. On the other hand, reform of Judaism itself so as to bring this authentic, spiritual form of Judaism into existence. As a result, there would no longer be a need for Christian missionaries to inculcate a 'living religion' among her brethren. (iv) Aguilar became obsessed with the goal of capturing and conveying the ephemeral sense of relation, of shared-but-distinct identity, between Jew and Christian. It was not easy for her to articulate this perceived reality and she drew upon all her skills, expressing the complex sense of religious identity in different literary forms and genres. This observation is useful for explaining Aguilar's unusual combination of writing styles, which range from the 'edifying literature' of her novels, poetry, and dialogues, to formal works of exegesis and theology. Finally, (v) the ambiguity of Aguilar's appreciation of Christianity reflects the fact that her analysis was not a linear investigation offering a definitive conclusion, but rather a dynamic process. The evidence from her writings strongly suggests that she was forever oscillating between that which differentiates or pushes apart and that which binds together or unifies.

\section{BIBLIOGRAPHY}

Ahad Ha-Am. 'Judaism and the Gospels' in The Fewish Review, I (3 September 1910).

Aguilar, Grace. Home Influence: A Tale for Mothers and Daughters. London: R. Groombridge, 1847.

- Records of Israel. London: J. Mortimer, 1844.

. Sabbath Thoughts and Sacred Communings. London: Groombridge and Sons, 1853.

The Ferwish Faith: Its Spiritual Consolation, Moral Guidance and Immortal Hope. Philadelphia: L. Johnson, 1846.

- The Magic Wreath of Hidden Flowers. Brighton: W.H. Mason, 1839.

. The Spirit of Fudaism. Edited by Isaac Leeser. Philadelphia: Jewish Publication Society of America, 1842.

. The Vale of Cedars, or, the Martyr. London: Groombridge and Sons, 1850.

. The Women of Israel, or, Characters and Sketches from the Holy Scriptures and Fewish History, Illustrative of

the Past History, Present Duties, and Future Destiny of the Hebrew Females, as Based on the Word of God. London:

Routledge, 1845.

Aguilar, Grace, and Sarah Aguilar. Essays and Miscellanies. Philadelphia: A. Hart, 1853.

Asch, Sholem. The Nazarene. Trans. by Maurice Samuel. New York: Putnam, 1939.

—. Mary. Trans. by Leo Steinberg. New York: G.P. Putnam’s Sons, 1949. 
Asch, Sholem. The Apostle. Trans. by Maurice Samuel. London: Macdonald, 1949.

Belais, Abraham. Biblical Expositions. London: A. Belais, 1844.

Carmichael, Joel. The Satanizing of the Jews: Origin and Development of Mystical Anti-Semitism. 1st U.S. ed. New York: Fromm International Pub. Corp., 1992.

Danby, Herbert. The Few and Christianity; Some Phases, Ancient and Modern, of the Fewish Attitude Towards Christianity. London: Sheldon Press, 1927.

D'Israeli, Isaac. The Genius of Fudaism. London: E. Moxon, 1833.

Ellis, Sarah Stickney. The Women of England, Their Social Duties and Domestic Habits. London: Fisher, 1839.

Flannery, Edward H. The Anguish of the Jewes: Twenty-Three Centuries of Anti-Semitism. New York: Macmillan, 1965.

Galchinsky, Michael. The Origin of the Modern fewish Woman Writer: Romance and Reform in Victorian England. Detroit: Wayne State University Press, 1996.

Grace Aguilar: Selected Writings. Peterborough, Ont.; Orchard Park, NY: Broadview Press, 2003.

Isaac, Jules. The Teaching of Contempt: Christian Roots of Anti-Semitism. 1st ed. New York: Holt, 1964.

Keith, Alexander. Evidence of Prophecy. Edinburgh: Waugh \& Innes, 1823.

Kershen, Anne, and Jonathan Romain. Tradition and Change: A History of Reform Fudaism in Britain, 1840 1995. London: Vallentine Mitchell, 1995.

Klausner, Joseph. Jesus of Nazareth; His Life, Times, and Teaching. New York: Macmillan, 1929.

Langton, Daniel. Claude Montefiore: His Life and Thought. Parkes-Wiener Series on Jewish Studies. London: Vallentine Mitchell, 2002.

"A Question of Backbone: Comparing Christian Influences Upon the Origins of Reform and Liberal Judaism in England" in Melilah 3 (2004).

"Piety, Tradition and Community in the Thought of Lily Montagu: An Anglo-Liberal Jewish Theology of Relation" in Women in Fudaism: A Multidisciplinary fournal 7:2 (2010).

Lask-Abrahams, Beth-Zion. "Grace Aguilar: A Centenary Tribute" in Fewish Historical Society of England Transactions 16 (1952).

Lieberman, Chaim. The Christianity of Sholem Asch: An Appraisal from the Jewish Viewpoint. Trans. by A. Burstein. New York: Philosophical Library, 1953.

Littell, Franklin H. The Crucifixion of the Jewes. 1st ed. New York: Harper \& Row, 1975.

Meyer, Michael. Response to Modernity: A History of the Reform Movement in Fudaism. Oxford: Oxford University Press, 1988.

Montefiore, Claude G. The Synoptic Gospels. 2nd edn, 2 vols. London: Macmillan, 1927.

Page, Judith W. Imperfect Sympathies: Feres and Fudaism in British Romantic Literature and Culture. London: Palgrave, 2004.

- "Anglo-Jewry and the Politics of Cultivation in Hazlitt, Aguilar and Disraeli" in Spector, Sheila A. The Fewes and British Romanticism: Politics, Religion, Culture. New York; Basingstoke: Palgrave Macmillan, 2005.

Parkes, James. The Conflict of the Church and the Synagogue: A Study in the Origins of Antisemitism. London: The Soncino Press, 1934.

Radford-Ruether, Rosemary. Faith and Fratricide: The Theological Roots of Anti-Semitism. New York: Seabury Press, 1974.

Ragussis, Michael. Figures of Conversion: Fewish Question and the English National Identity. Durham: Duke University Press, 1995.

Saperstein, Marc. Moments of Crisis in Fewish-Christian Relations. London: SCM Press, 1989.

Scheinberg, Cynthia. Women's Poetry and Religion in Victorian England: Jewish Identity and Christian Culture, Cambridge Studies in Nineteenth-Century Literature and Culture 35. Cambridge, UK ; New York: Cambridge University Press, 2002.

Schoeps, Hans Joachim. The Jewish-Christian Argument: A History of Theologies in Conflict. Translated by David E. Green. 1st ed. New York: Holt, 1963. 
Sheleff, Leon Shaskolsky. In the Shadow of the Cross: Fewish-Christian Relations through the Ages. London: Vallentine Mitchell, 2004.

Spector, Sheila A. The Jews and British Romanticism: Politics, Religion, Culture. New York; Basingstoke: Palgrave Macmillan, 2005.

Steiman, Lionel B. Franz Werfel: The Faith of an Exile. Ontario: Wilfrid Laurier University Press, 1985.

Valman, Nadia. The Jewess in Nineteenth-Century British Literary Culture, Cambridge Studies in NineteenthCentury Literature and Culture. Cambridge: Cambridge University Press, 2007.

Werfel, Franz. Paulus unter den Fuden. Berlin: Zsolnay, 1926.

. Paul Among the feres: A Tragedy. Trans. by Paul Levertoff. London: A.R. Mowbray \& Co., 1928. 